\title{
Sunshine duration and its variability in the main ridge of the Karkonosze Mountains in relation to with atmospheric circulation
}

\author{
Grzegorz Urban $^{1} \cdot$ Krzysztof Migala $^{2} \cdot$ Piotr Pawliczek $^{2}$
}

Received: 17 June 2016 / Accepted: 5 January 2017 /Published online: 20 January 2017

(C) The Author(s) 2017. This article is published with open access at Springerlink.com

\begin{abstract}
Sunshine duration analysis was based on a series of measurements spanning the period from 1901 to 2014 for Śnieżka (1603 m a.s.l.) and from 1961 to 2000 for Szrenica (1362 $\mathrm{m}$ a.s.l.). The average annual sunshine duration (SD) on Śnieżka is $1423.0 \mathrm{~h}$, which is among the lowest values in Poland. On average, the main ridge of the Karkonosze range receives $31 \%$ of potential sunshine duration in annual terms: from $25 \%$ in December to $36 \%$ in August and May. The changes in sunshine duration recorded on Śnieżka point to the existence of two cycles: a short one of approx. 2-4 years and a long one of approx. 60 years. The former most probably reflects the rhythm of atmospheric circulation in the North Atlantic (North Atlantic Oscillation), while the latter reflects the impact of ocean circulation associated with the AMO (Atlantic Multidecadal Oscillation) mechanism. Annual SD totals for the years 1901-2014 exhibit a slight trend to an increase of approx. $2.5 \mathrm{~h} / 10$ years, and the rate of increase during the winter quarter is many times higher than during the other seasons. Average monthly sunshine duration differences between Śnieżka and Szrenica are positive for all months of the year with the average monthly difference being
\end{abstract}

Grzegorz Urban

grzegorz.urban@imgw.pl; urbag@ @oczta.onet.pl

Krzysztof Migała

krzysztof.migala@uwr.edu.pl

Piotr Pawliczek

piotr.pawliczek@uwr.edu.pl

1 Institute of Meteorology and Water Management-National Research Institute, Podleśna Street 61, 01-673 Warsaw, Poland

2 Institute of Geography and Regional Development, University of Wrocław, Pl. Uniwersytecki 1, 50-137 Wrocław, Poland
10 to $11 \mathrm{~h}$. This means that the average radiation conditions on Śnieżka are more favourable than the main ridge of the Karkonosze range, which lies at an altitude 200 to $250 \mathrm{~m}$ lower. Average daily sunshine durations recorded on Śnieżka are only shorter than those on Szrenica for macro-types of atmospheric circulation with advection from the south.

\section{Introduction}

Sunshine duration trends are among the most important issues in studies of climate change, since sunshine duration affects the Earth's radiation and energy balance. At the same time, changes in sunshine duration are among those indicators of contemporary climate change that are sensitive to changes in atmospheric circulation (Dubicka 1997). In Poland, the first analyses of sunshine duration as a function of atmospheric circulation were conducted in the 1950s (Trybowski 1955; Michalczewski 1959). Orliczowa (1968) studied the variability of cloud cover and sunshine in the hypsometric profile of the Tatra Mountains. Later Polish publications on sunshine duration in the mountains included work on the variability of sunshine duration in the hypsometric profile of the Western Carpathians (Limanówka and Ustrnul 1993) and its variability in the Sudetes and Carpathian Mountains, including their foreland (Dubicka and Limanówka 1994). Significant studies of the problem of sunshine duration in the Karkonosze Mountains include an article on the Śnieżka climate during the 1961-1990 multi-annual period (Głowicki 1995), the variability of sunshine duration on Śnieżka in connection with atmospheric circulation and cloud cover in the years 1901-1995 (Dubicka 1997) and on Szrenica in the years 1961-1990 (Dubicka and Karal 1994).

In foreign literature, a methodical study concerning the variability of cloud cover and sunshine duration on the 
territory of the USA, based on data for the years 1950-1982 gathered from more than 100 measuring stations, was conducted by Angell et al. (1984). Causes of long-term changes in sunshine duration are not entirely known. Sunshine duration trends have been described, e.g. for Western Europe on the basis of data from 79 stations in 7 countries (SanchezLorenzo et al. 2008). These indicate that all changes are the result of long-term variations in the supply of solar radiation on the macro scale, which are only modified by local conditions. The results presented in the study confirm the slightly downward trends in annual sunshine duration observed in other places, e.g. in Central and South-Eastern Europe (Brázdil et al. 1994), in the Czech Republic (Bednar 1990), in Slovakia (Horecka 1990), in Germany (Weber 1990), in Austria (Dobesch 1992), in Spain (Sanchez-Lorenzo et al. 2007), in India (Jhajharia and Singh 2011) and in Poland (Morawska-Horawska 1984, 1985; Dubicka 1997; Matuszko 2014). Weber (1990) found no statistical relationships between sunshine duration trends and changes in other meteorological parameters. At the same time, he found that the sunshine duration trend was caused by changes in atmospheric circulation on the macro scale. Auer et al. (1990), basing their study on data from the Sonnblick station in the Alps, found a positive correlation between sunshine duration on the one hand and air temperature and atmospheric pressure trends on the other. Dobesch (1992) found a correlation between the annual total of sunshine duration and absolute altitude - an increase of $0.7 \mathrm{~h} / 100 \mathrm{~m}$ in the zone above $900 \mathrm{~m}$ a.s.l. Additionally, he noted that sunshine duration variance was the lowest in the 900-m a.s.l. zone.

From the 1950s to the 1980s, a decline in the intensity of solar radiation was observed (Stanhill and Cohen 2001; Liepert 2002). This phenomenon was dubbed "global dimming". Later research demonstrated that from the mid1980s onwards, an increase in solar radiation followed, which was referred to as "global brightening" (Wild et al. 2005; Pinker et al. 2005). Reasons for shifts in radiation trends have not been fully determined; these may result from changes in atmospheric transparency caused by variations in cloud cover or concentrations of anthropogenic aerosols (Wild 2009). Much of the work focused on studying series of insolation measurements; multi-annual insolation series are an easy way to characterise the variability and spatial distribution of solar radiation. This problem was studied by Angell (1990), and Stanhill and Cohen (2005) in the USA, by Pallé and Butler (2001) in Ireland and by Kaiser and Qian (2002) and Yang et al. (2009) in China. In these papers, a decrease in sunshine duration was reported starting in the early 1950s. From 1950 to 1980 , a downward trend in annual totals of sunshine duration was observed in the Iberian Peninsula, followed by an upward trend from the mid-1980s until the end of the century (Sanchez-Lorenzo et al. 2008). An important work that covered as many as 237 stations grouped into the five climatic regions and concerned, inter alia, sunshine duration trends from 1961 to 2004 in six South American countries, was published by Raichijk (2012). The results of that study confirm downward trends in sunshine duration from the 1950s until the 1980s and upward ones since the beginning of the 1990s, which were also observed in other regions of the world. Satellite short-wave radiation data spanning the period from 1984 to 2005 confirm the results obtained at ground sunshine duration measurement stations in all five climatic regions of South America. Upward sunshine duration trends are associated with an increase in the intensity of solar radiation and a decrease in cloud cover (Raichijk 2012). It should be stressed that both insolation and cloud cover are primarily related to atmospheric circulation and are influenced by heat balance and local conditions (Dubicka and Limanówka 1994).

The purpose of this paper is to describe sunshine duration (SD) and analyse its trends in the main ridge of the Karkonosze Mountains in relation to atmospheric circulation.

\section{Characteristics of stations and measurement series}

The analysis was based on measurement data from the Śnieżka High Mountain Meteorological Observatory, Institute of Meteorology and Water Management-National Research Institute on Śnieżka (1603 m a.s.l.), and from the meteorological observatory of the University of Wrocław on Szrenica.

Śnieżka (SN) is the highest peak of the Karkonosze range (1603 m a.s.l.), and the Karkonosze are the highest part of the Sudetes - the largest mountain range in south-western Poland. It is an exposed summit with geographic coordinates $\varphi 50^{\circ} 44^{\prime}$ $\mathrm{N}$ and $\lambda 15^{\circ} 44^{\prime} \mathrm{E}$. Szrenica (SZ) is a peak (1362 $\mathrm{m}$ a.s.l.) with geographic coordinates $\varphi 50^{\circ} 48^{\prime} \mathrm{N}$ and $\lambda 15^{\circ} 31^{\prime} \mathrm{E}$, in the Western Karkonosze range. It belongs to the main ridge of the Karkonosze Mountains and is situated within the dwarf pine belt. According to the classification by Ellenberg (1978), both peaks belong to the sub-alpine climate zone. According to Hess (1968), Szrenica and Śnieżka are located in the very cool climate zone with an average annual air temperature ranging from 0 to $2{ }^{\circ} \mathrm{C}$.

Measurements of SD on Śnieżka started on 1 July 1900. This series, alongside those compiled at such observatories as Sonnblick or Zugspitze, is among the longest recorded at high mountain stations in Central Europe. The measurements were conducted using the Campbell-Stokes heliograph. Over the entire period of sunshine duration measurements on Śnieżka, the location of measuring instruments changed once. From 1 July 1900, the Campbell-Stokes heliograph was located on a platform within the former meteorological observatory building, ca. $16 \mathrm{~m}$ above ground level. Since 23 October 1976, it has been located on the balustrade of the upper terrace of the new observatory, at a height of ca. $14 \mathrm{~m}$ above ground level 
(Fig. 1). Thus, the changes only concerned the location of the heliograph within the new building, which remained in the small Śnieżka summit area. The physical horizon of the heliograph was and remains open and the instrument was not obscured by obstacles at any time. These changes had no effect on measurement series homogeneity (Dubicka 1997).

On the summit of Szrenica, the meteorological observatory of the Department of Meteorology and Climatology of the University of Wrocław operated from 1957 to 2002. SD recording on Szrenica using the Campbell-Stokes heliograph started on 1 July 1957, using a tower constructed on the summit at $1364.5 \mathrm{~m}$ a.s.1., approx. $80 \mathrm{~m}$ SSE from the mountain refuge. The physical horizon of the heliograph was sufficiently open so that the highest obstacles from the SSE did not exceed $3^{\circ}$ (Dubicka and Karal 1994).

Śnieżka and Szrenica are the only locations in the main ridge of the Karkonosze range (and in the entire Sudetes) where homogeneous sunshine duration measurements have been conducted in the period from 1961 to 2000, and at the same time, they are situated very close to each other. The distance between them is approx. $20 \mathrm{~km}$ and the difference in altitude is approx. $240 \mathrm{~m}$. In addition, the two peaks, and especially Śnieżka, represent climatic conditions similar to those prevailing in the free atmosphere, and they well document the warming process that is observed on a global scale
(Sobik et al. 2014). The strong positive correlation between these two stations (in the years from 1961 to 2000 when they operated simultaneously) demonstrated further in this paper, and the 114-year measurement series from Śnieżka provide unique test material for examining changes in sunshine duration in the context of climate variability in mountain conditions in Central Europe. A phenomenon characteristic of Śnieżka and Szrenica is the high incidence of fog. It is recorded for 296 days (SN) and 274 days (SZ) during the year, placing these summits respectively in the first and fifth places in terms of the incidence of fog at mountain weather stations on mainland Europe (Błaś and Sobik 2000). One consequence of fog is the atmospheric deposit in the form of rime, which is present for 7-9 months per year (Migała et al. 2002).

\section{Source data and method}

Monthly totals of sunshine duration on SN from the years 1901-2014 and on SZ from the years 1961-2000 provided the primary source material for this paper. Observational data were prepared for the entire year (I-XII), the warm half-year $(\mathrm{V}-\mathrm{X})$, the cold half-year (XI-IV) and for quarterly seasons, i.e. winter (XII-II), spring (III-V), summer (VI-VIII) and autumn (IX-XI) as well as for individual months of the year

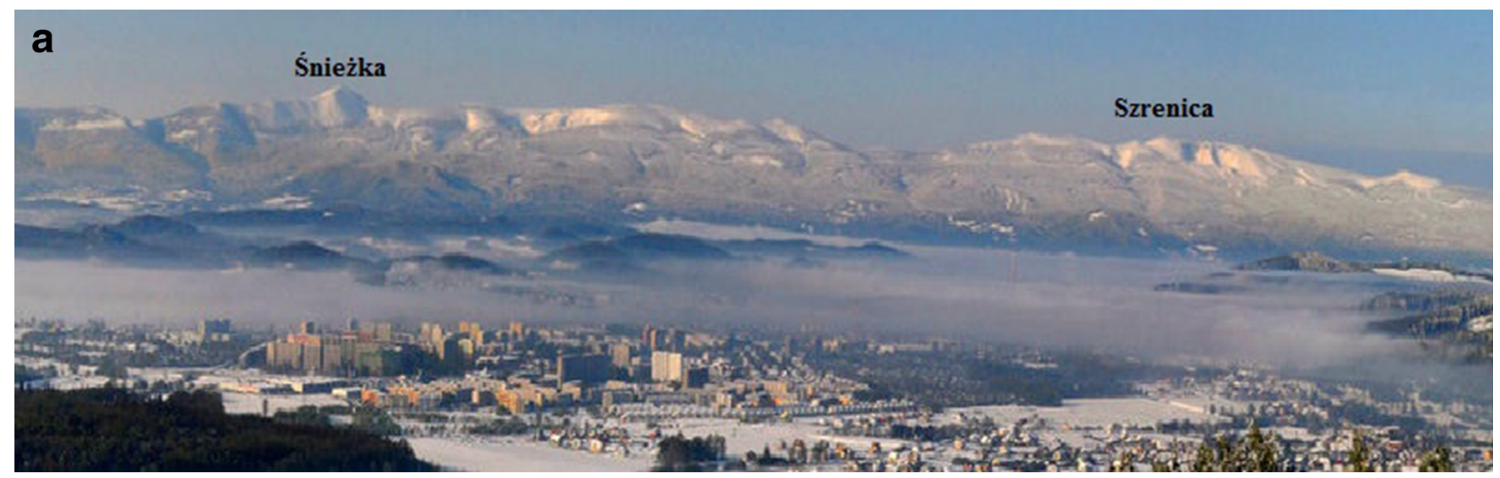

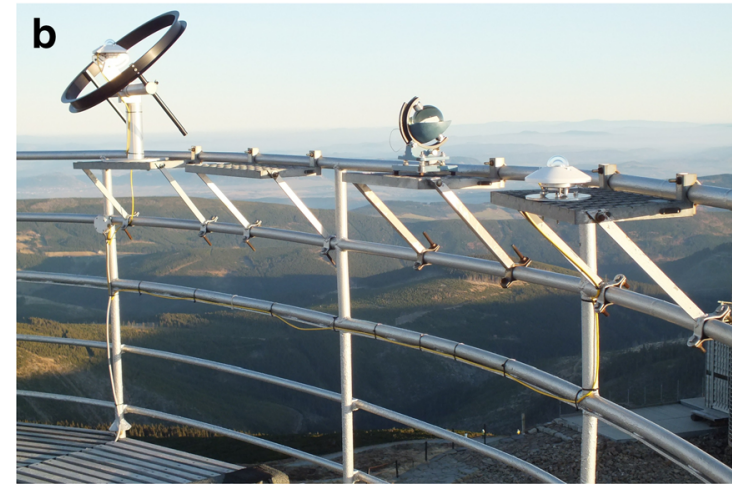

Fig. 1 View of the Karkonosze range from the north (a); instruments recording solar radiation including the Campbell-Stokes heliograph on the balustrade of the Śnieżka Observatory terrace (b) and actinometric tower at the Szrenica Observatory (c). Photo (a): R. Stypiński (Urząd

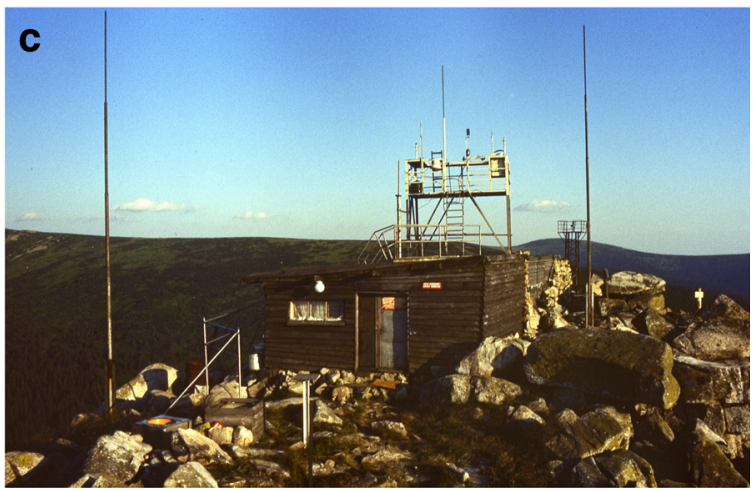

Miasta Jelenia Góra) [CC BY-SA 3.0 (http://creativecommons. org/licenses/by-sa/3.0)], Wikimedia Commons; Photo (b): G. Urban; Photo: (c): W. Gorączko 
(I, II, ..., XII). The focus was mainly on monthly values, since 1 month is the time span usually used in comparative and spatial sunshine duration analyses (Kerr and Tabony 2004).

Daily totals of sunshine duration from both stations from the period of their simultaneous operation, i.e. from the full 40-year period from 1961 to 2000 , were also used. For this multi-annual period, a relationship was determined between Śnieżka and Szrenica with respect to annual totals of sunshine duration. For the 1961-2000 multi-annual period, differences between Śnieżka and Szrenica in daily totals of sunshine duration were also determined, which were assigned to circulation macrotypes according to the classification compiled by Hess and Brezowsky (1952, 1977). For large SD differences (i.e. several hours during the day), detailed analyses of their causes were carried out through reference to atmospheric circulation macro-types. A description of circulation macro-types is presented later in this work, in Table 2 in Section 4.2.

The starting point for establishing the relationship between sunshine duration and atmospheric circulation was the calendar of atmospheric circulation macrotypes compiled for the period from 1901 to 2014 (Hess and Brezowsky 1977; Werner and Gerstengarbe 2010). Data for the years 2010-2014 were obtained from the online resources of the Deutscher Wetterdienst (www. dwd.de).

Using simple regression equations and standard deviation values, a variability analysis was conducted for the homogeneous SD series from Śnieżka and Szrenica for the years 1901-2014 and 1961-2000. Analogously, the trends relating to changes in atmospheric circulation macro-types during the period 1901-2014 were determined. The statistical significance of the trends determined at a significance level of 0.05 was verified using Student's $t$ test.

\section{Results and discussion}

\subsection{Characteristics of sunshine duration and trends}

The comparison of the results of sunshine duration measurements on SN with sunshine duration measurements on SZ indicates a strong positive correlation for annual, seasonal and monthly totals. The correlation coefficient $(R)$ ranges from 0.81 in winter to $0.94-0.97$ in other seasons and over the entire year. A sample relationship for the stations analysed in terms of annual totals is shown below (Fig. 2). Such a high correlation coefficient enables the results of multi-annual sunshine duration observations to be generalised from Śnieżka to the entire main ridge of the Karkonosze range.

The average annual total of sunshine duration in the 19012014 multi-annual period on Śnieżka is 1423.0 h, i.e. among the lowest values in Poland (Dubicka 1997; Lorenc et al. 2005). In the main ridge of the Karkonosze, adverse weather conditions associated with a high degree of cloudiness and lack of sunshine are the result of the presence of orographic clouds, particularly those associated with a föhn (Kwiatkowski and Hołdys 1985).

The highest average SD values during the year were found for the following months (in descending order): May (171.7 h), July (167.9 h) and August (163.8 h) (Fig. 3). The May SD maximum is the result of a low degree of cloudiness, which is due to the limited share of western cyclonic (Wz) circulation during this month; the annual share of this circulation macro-type stands out compared to the other macro-types and averages $15.4 \%$ during the multi-annual period (Table 2). In turn, the reduction in the average SD total in June is caused by the highest degree of cloudiness during the warm half of the year and the large number of cloudy days (Dubicka 1997). This phenomenon is characteristic of the solar climate of the higher parts of the Sudetes and Carpathians (Stenz 1959; Głowicki 1995). This is confirmed by the June dominance
Fig. 2 Relationship between annual totals of sunshine duration on Śnieżka (SN) and Szrenica (SZ) in the 1961-2000 multiannual period

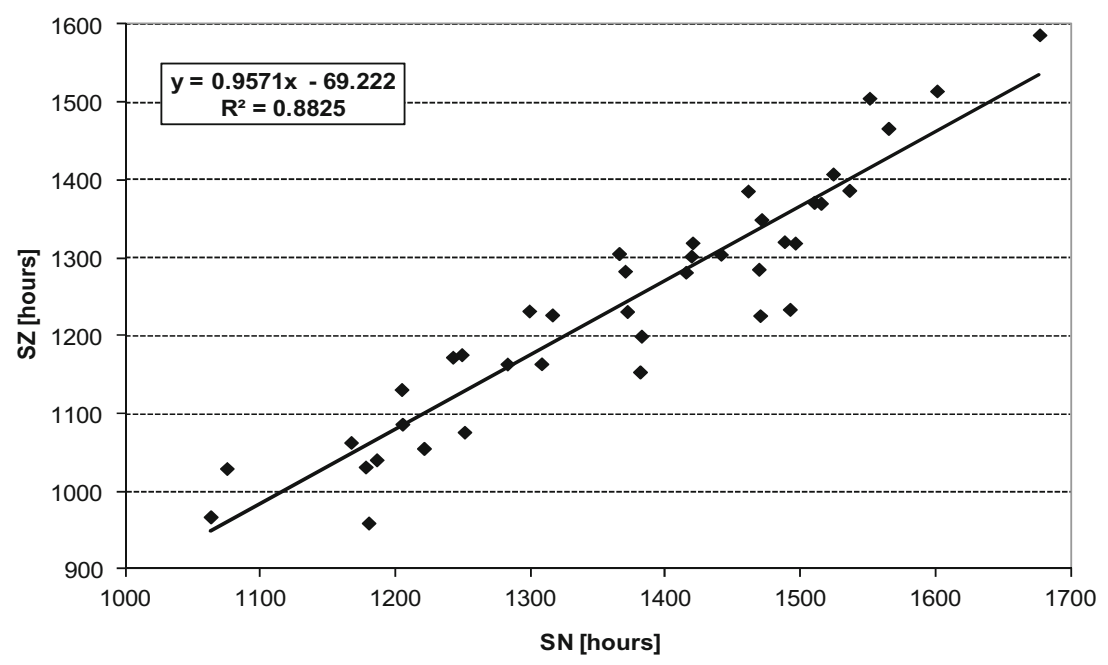


Fig. 3 Annual changes in sunshine duration $(\mathrm{SD})$ on Śnieżka from 1901 to 2014 averages and extreme monthly totals

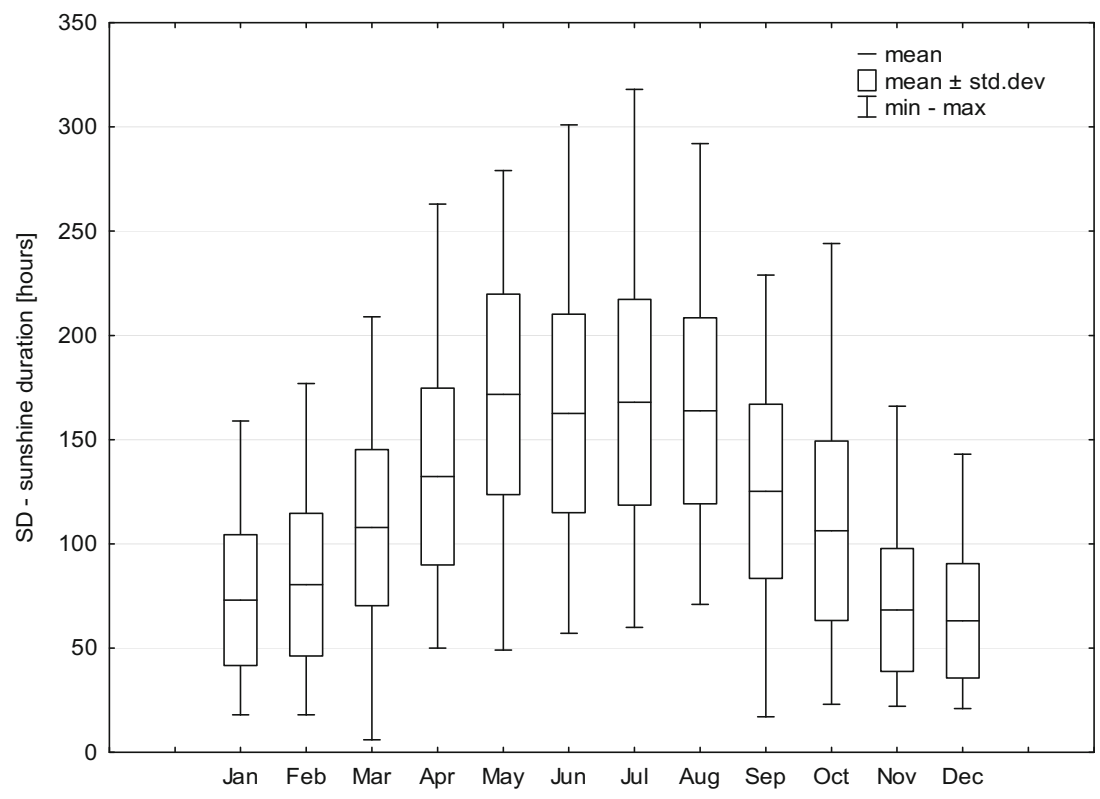

of the Wz circulation whose incidence during the 1901-2014 multi-annual period was the highest and amounted to $14.9 \%$. The lowest average monthly SD total occurs in December at $63.1 \mathrm{~h}$. This is due to the low position of the sun above the horizon and the short day. The highest monthly SD total $(318 \mathrm{~h})$ in the entire history of measurements on Śnieżka was recorded in July 2006. It was the result of the dominance of anticyclonic circulation over Central Europe (BM)38.7\%. The minimum (6 h) was in March 2009 (Fig. 3). At that time, north-western cyclonic circulation (NWz) was dominant $(35.5 \%)$.
Relative sunshine duration (RSD), i.e. the ratio of actual to potential sunshine duration, is more evenly distributed during the year and better reflects the weather conditions prevailing during the month in question (Fig. 4). This ranges (on average) from $26 \%$ in December to $37.1 \%$ in August. There was a clearly marked RSD maximum in October 1943, which amounted to $73.4 \%$ and far exceeded relative peaks from the other months (Fig. 4). This was probably related to the dominance of the HM (high pressure over Central Europe) circulation macro-type during that month, which caused air to subside within the anticyclone. The HM macro-type accounted
Fig. 4 Annual changes in relative sunshine duration (RSD) on Śnieżka from 1901 to 2014 averages and extreme monthly totals

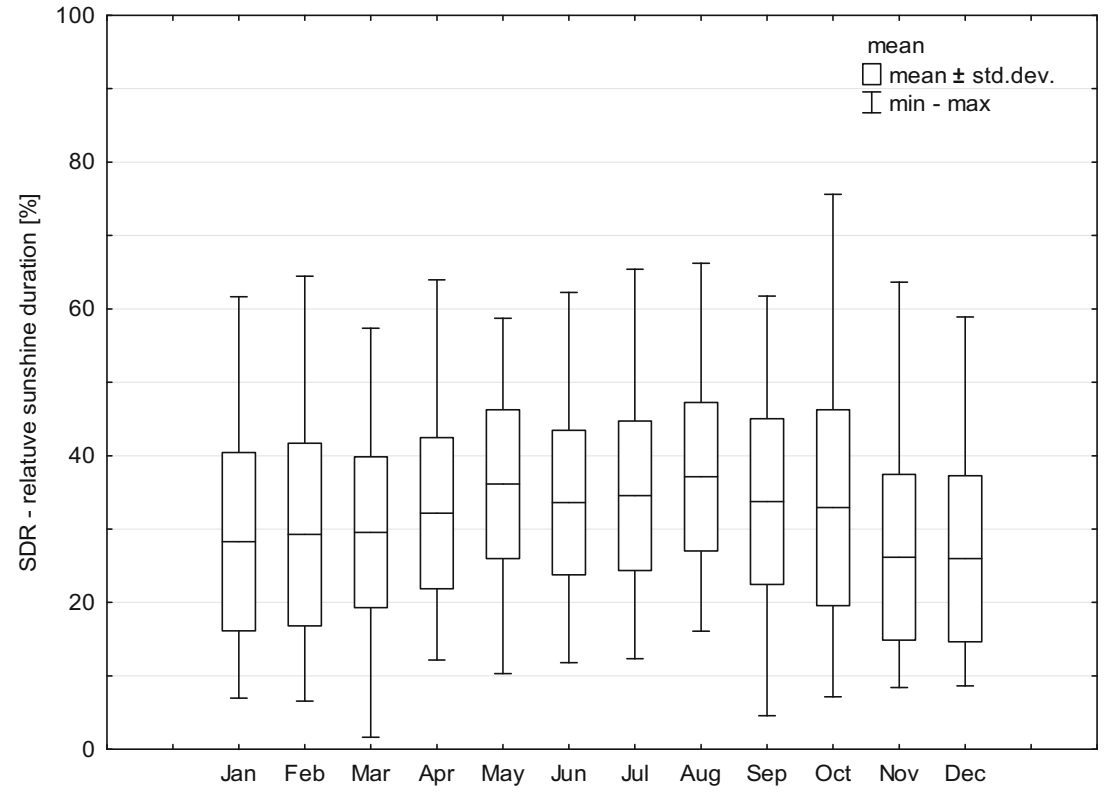


for as much as $45 \%$ of all circulation macro-types in October 1943. The absolute RSD minimum at $1.6 \%$ was found in March 2009. This was a period when the north-western cyclonic circulation prevailed (35.5\%), generating an influx of moist air masses that contributed to a high degree of cloudiness. On average, the main ridge of the Karkonosze range receives $31 \%$ of potential sunshine duration during the year. This result is consistent with previous results obtained for the period from 1951 to 1975 for Śnieżka and Kasprowy Wierch (Kuczmarski 1990) and from 1901 to 1995 for Śnieżka (Dubicka 1997).

A characteristic feature of SD is its great variability. The greatest variability as expressed by the largest standard deviation values $(48-49 \mathrm{~h})$ is typical of the months in the warm half-year: July, May and June (in descending order) (Fig. 3). On the other hand, the lowest variability is found in the winter quarter, with standard deviation values ranging from $28 \mathrm{~h}$ in December to $34 \mathrm{~h}$ in February. Large differences in actual sunshine between summer and winter are due to daylength. In the case of RSD, the variability expressed in terms of standard deviation is evenly distributed during the year and ranges from $9.8 \%$ in June to $13.3 \%$ in October (Fig. 4).

The results of spectral analysis of sunshine duration on Śnieżka in the years 1901-2014 point to the existence of two cycles: a short one of approx. 2-4 years and a long one of approx. 60 years (Fig. 5). The former most probably reflects the rhythm of atmospheric circulation in the North Atlantic (North Atlantic Oscillation), while the latter reflects the impact of ocean circulation associated with the AMO (Atlantic Multidecadal Oscillation) mechanism (Schlesinger and Ramankutty 1994; Enfield et al. 2001; Portis et al. 2001; Zhang et al. 2011). Similar relationships have been identified in the case of multi-annual changes in air temperature in the Karkonosze range (Migała et al. 2015).
The highest annual SD total of $2017 \mathrm{~h}$ was recorded on Śnieżka in 1921, and the lowest one of 922 h in 1912 (Fig. 6). The reason for such a low SD value in 1912 could be the Novarupta volcanic eruption in Alaska (Oman et al. 2005). It occurred on 6 June 1912 and was the largest volcanic eruption in the twentieth century. The Wz circulation pattern, which was dominant both during that month $(43.3 \%)$ and in subsequent months, could have led to a marked reduction in sunshine duration, including on Śnieżka.

Apart from the year 1912, low annual totals of sunshine duration occurred in 1981 and 1966 and amounted to 1063 and $1075 \mathrm{~h}$, respectively. During the 114-year series of sunshine duration measurements analysed, the period from the beginning of measurements until the 1920 s was characterised by a marked increase in annual totals of SD. It was in this period that the maximum maximorum of the annual totals occurred at $2017 \mathrm{~h}$, which was recorded in 1921. On the other hand, the period from the early 1950s until the early 1980 s brought a marked reduction in annual totals of sunshine duration (Fig. 6). The decrease in annual totals of sunshine duration, which lasted from the late 1940s until the 1970s, was the most pronounced feature of changes in this parameter observed in Central Europe (Brázdil 1991). A similar trend was observed during that period on the Sonnblick in the Alps (Dobesch 1992) and in central Germany (Weber 1990) and also in the Czech Republic and Slovakia (Vaniček 1990). The decrease in sunshine duration in the years 1951-1987 in central Germany was associated with an increase in the incidence of cyclonic systems (Weber 1990). A similar reason is given by Vaniček (1990) for the same period in the Czech Republic and Slovakia.

The relationship between the increase in cloudiness and the decrease in sunshine is evident (Angell et al. 1984, Henderson-Sellers 1986, Brázdil 1991). However, an increase in anthropogenic air pollution may lead to a drop in sunshine
Fig. 5 Spectral analysis periodogram of annual sunshine duration totals on Śnieżka

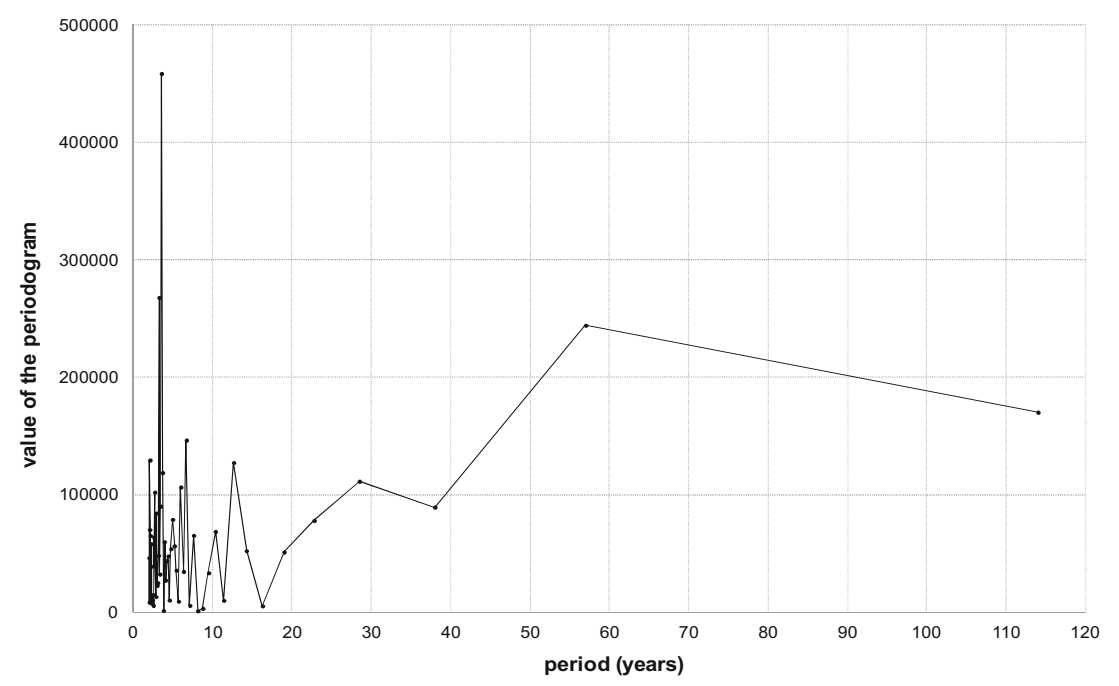


Fig. 6 Annual totals of sunshine duration (SD) on Śnieżka in the 1901-2014 period with the trend line (black, bold) and seven-year moving average (red, bold) marked

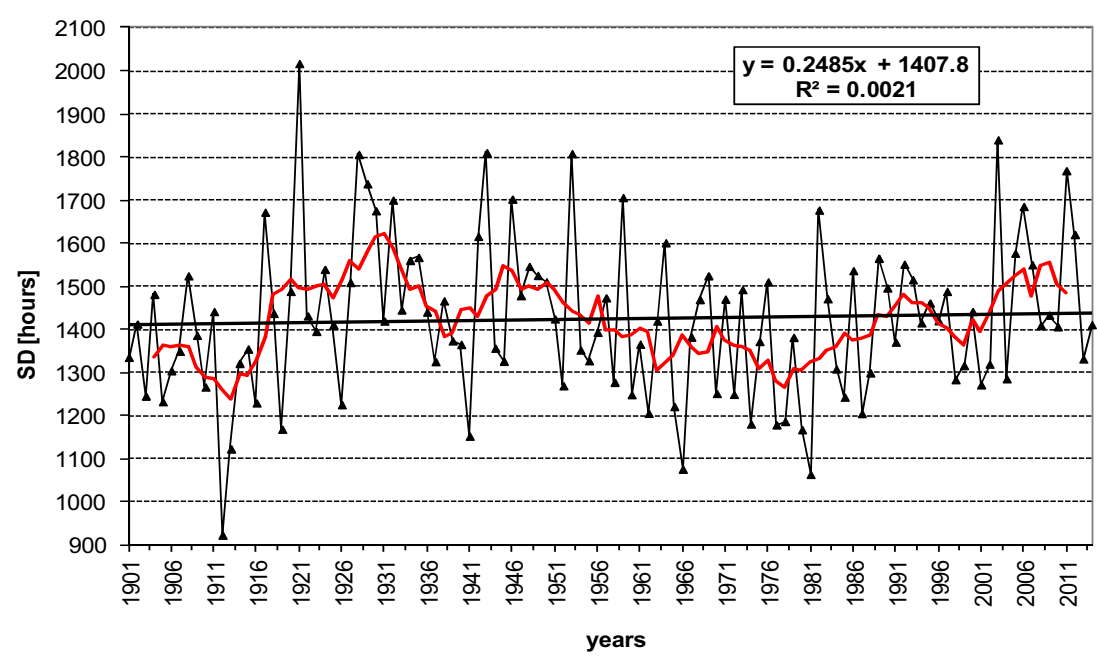

duration without a change in cloud cover, especially in valleys (Dubicka and Limanówka 1994). The global trend observed was related to the well-documented phenomenon of "global dimming" and the reduction in the intensity of direct solar radiation as a result of the increased content of aerosols and dust of anthropogenic origin in the atmosphere (Stanhill and Cohen 2001; Liepert 2002).

Towards the end of the twentieth century, this trend was reversed, which was described as "global brightening" (Wild et al. 2005). Since the late 1990s, an increase in annual totals of sunshine duration has been observed. In 2003, a secondary annual maximum amounting to $1840 \mathrm{~h}$ was recorded (Fig. 6).

Annual SD totals for the years 1901-2014 exhibit a slight upward trend of ca. $2.5 \mathrm{~h} / 10$ years. A similar trend can be seen in the totals for the cold half-year. In the warm half-year, there is virtually no trend (the directional factor is close to zero). However, the rate of increase in the cold half-year or in the winter quarter is significantly higher than in the analogous warm seasons. For individual months, no regularities were identified since there are both slightly positive trends (II-IV, VII-VIII, X, XII) and slightly negative ones (I, V-VI, IX, $\mathrm{XI}$ ). The trends determined, except for April, are not statistically significant at a significance level of 0.05 (Table 1). The increase in sunshine duration in winter is characteristic of changes in that parameter that take place not only in the highest parts of the Sudetes (Śnieżka) but also on Kasprowy Wierch in the Tatra Mountains (Dubicka and Limanówka 1994).

However, three periods can be distinguished with respect to annual SD on Śnieżka. The first one-from the beginning of the measurements until the 1920 s - was characterised by a marked increase in SD values. The second one-from the late 1920s to the mid-1980s - saw a marked decline in SD totals. The upward trend in SD on Śnieżka in that period closely followed the trends observed in other areas of Europe and of the world cited in this paper. The third period, which has lasted

since the mid-1980s, has brought a noticeable upward trend in annual totals of SD (Fig. 6).

\subsection{Impact of atmospheric circulation on sunshine duration}

The frequency distribution of individual circulation macrotypes shows that the 1901-2014 multi-annual period was dominated by the following six macro-types, Wz, BM, HM,

Table 1 Sunshine duration $(\mathrm{SD})$ trends [hours/10 years] on Śnieżka in the 1901 2014 period

\begin{tabular}{ll}
\hline Period & SD \\
\hline Year (I-XII) & 2.485 \\
Warm half-year (V-X) & -0.035 \\
Cold half-year (XI-IV) & 2.52 \\
Spring (III-V) & 2.074 \\
Summer (VI-VIII) & 0.705 \\
Autumn (IX-XI) & -1.206 \\
Winter (XII-II) & 1.314 \\
January (I) & -0.141 \\
February (II) & 0.720 \\
March (III) & 0.014 \\
April (IV) & $2.566^{\mathrm{a}}$ \\
May (V) & -0.506 \\
June (VI) & -1.575 \\
July (VII) & 0.054 \\
August (VIII) & 2.226 \\
September (IX) & -1.361 \\
October (X) & 1.127 \\
November (XI) & -0.972 \\
December (XII) & 0.332 \\
\hline
\end{tabular}

${ }^{\mathrm{a}}$ Means that the trend is statistically significant at a significance level of 0.05 
Wa, NWz and TRM, which were active on $46.9 \%$ of days in total. The Wz macro-type was the most frequent at $15.4 \%$, followed by BM ( $8.5 \%)$ and $\mathrm{HM}(8.0 \%)$, while the frequency of the remaining three hovered around 5.0\% (Table 2). During the 1901-2014 period, the incidence of atmospheric circulation macro-types occurring over Europe changed. On the basis of the correlation coefficient $(R)$, the nature of the trends associated with individual circulation macro-types was determined. It was assumed that $R$ in the range from 0.0 to 0.2 meant no change, $0.2-0.4$ was a slight change, $0.4-0.7$ was a moderate change, $0.7-0.9$ was a marked change and anything above 0.9 was a very marked change. Among the circulation macro-types distinguished by Hess and Brezowsky (1977), a moderate upward trend was identified with respect to the incidence of cyclonic zonal circulation with advection from the southwest (SWz). Similar trends were identified for

Table 2 Average annual incidence $N(\%)$, standard deviation $(\delta)$, correlation coefficient $(R)$ and trends of change in atmospheric circulation macrotypes during the 1901-2014 period

\begin{tabular}{|c|c|c|c|c|c|c|c|c|}
\hline No. & $\begin{array}{l}\text { Circulation } \\
\text { macro- } \\
\text { type symbol }\end{array}$ & Circulation macro-type description & $N[\%]$ & $\delta[\%]$ & $\begin{array}{l}\text { Rate of change/ } \\
10 \text { years }\end{array}$ & $R$ & Trend & $\begin{array}{l}\text { Significance at } \\
\text { a } 0.05 \text { level }\end{array}$ \\
\hline 1 & Wa & Western, anticyclonic & 5.5 & 2.91 & -0.131 & 0.15 & Slight decrease & No \\
\hline 2 & $\mathrm{Wz}$ & Western, cyclonic & 15.4 & 4.54 & 0.011 & 0.01 & No change & No \\
\hline 3 & Ws & Western, shifted to the south, cyclonic & 3.1 & 2.74 & -1.870 & 0.23 & slight decrease & Yes \\
\hline 4 & Ww & $\begin{array}{l}\text { Western, marginal, on the edge of the Russian } \\
\text { high-pressure zone }\end{array}$ & 2.3 & 1.90 & -0.018 & 0.03 & No change & No \\
\hline 5 & SWa & South-western, anticyclonic & 2.3 & 1.93 & 0.225 & 0.38 & Moderate increase & Yes \\
\hline 6 & SWz & South-western, cyclonic & 3.2 & 3.06 & 0.596 & 0.64 & Moderate increase & Yes \\
\hline 7 & NWa & North-western, anticyclonic & 3.5 & 2.73 & -0.399 & 0.48 & $\begin{array}{l}\text { Moderate } \\
\text { decrease }\end{array}$ & Yes \\
\hline 8 & NWz & North-western, cyclonic & 4.8 & 2.65 & 0.135 & 0.17 & Slight increase & No \\
\hline 9 & $\mathrm{HM}$ & High pressure over Central Europe, anticyclonic & 8.0 & 4.36 & -0.728 & 0.55 & $\begin{array}{l}\text { Moderate } \\
\text { decrease }\end{array}$ & Yes \\
\hline 10 & $\mathrm{BM}$ & $\begin{array}{l}\text { High-pressure ridge over Central Europe, } \\
\text { anticyclonic }\end{array}$ & 8.5 & 4.59 & 0.641 & 0.46 & Moderate increase & Yes \\
\hline 11 & $\mathrm{TM}$ & Depression over Central Europe, cyclonic & 2.3 & 1.76 & -0.075 & 0.14 & No change & No \\
\hline 12 & $\mathrm{Na}$ & Northern, anticyclonic & 0.8 & 1.06 & -0.047 & 0.15 & Slight decrease & No \\
\hline 13 & $\mathrm{Nz}$ & Northern, cyclonic & 2.7 & 2.24 & -0.223 & 0.33 & Slight decrease & Yes \\
\hline 14 & $\mathrm{HNa}$ & $\begin{array}{l}\text { High pressure over the North Sea-Iceland, } \\
\text { anticyclonic }\end{array}$ & 3.0 & 2.29 & -0.238 & 0.34 & Slight decrease & Yes \\
\hline 15 & $\mathrm{HNz}$ & $\begin{array}{l}\text { Depression over the North Sea-Iceland, } \\
\text { cyclonic }\end{array}$ & 1.6 & 1.72 & 0.138 & 0.27 & Slight increase & Yes \\
\hline 16 & HB & High pressure over the British Isles, anticyclonic & 3.2 & 2.23 & 0.047 & 0.07 & No change & No \\
\hline 17 & TRM & Trough over Central Europe, cyclonic & 4.7 & 3.40 & 0.390 & 0.38 & Slight increase & Yes \\
\hline 18 & $\mathrm{NEa}$ & North-eastern, anticyclonic & 2.0 & 2.04 & -0.259 & 0.42 & $\begin{array}{l}\text { Moderate } \\
\text { decrease }\end{array}$ & Yes \\
\hline 19 & $\mathrm{NEz}$ & North-eastern, cyclonic & 1.8 & 1.76 & -0.109 & 0.20 & Slight decrease & Yes \\
\hline 20 & $\mathrm{HFa}$ & High pressure over Fennoscandia, anticyclonic & 3.5 & 2.31 & -0.193 & 0.28 & Slight decrease & Yes \\
\hline 21 & $\mathrm{HFz}$ & $\begin{array}{l}\text { High pressure over Fennoscandia, not blocking } \\
\text { low pressure areas and fronts, cyclonic }\end{array}$ & 1.1 & 1.43 & 0.121 & 0.28 & Slight increase & Yes \\
\hline 22 & $\mathrm{HNFa}$ & $\begin{array}{l}\text { High pressure over the North Sea- } \\
\text { Fennoscandia, anticyclonic }\end{array}$ & 1.4 & 1.40 & 0.020 & 0.05 & No change & No \\
\hline 23 & $\mathrm{HNFz}$ & $\begin{array}{l}\text { High pressure over the North Sea- } \\
\text { Fennoscandia, cyclonic }\end{array}$ & 1.7 & 1.77 & 0.075 & 0.14 & No change & No \\
\hline 24 & $\mathrm{SEa}$ & South-eastern, anticyclonic & 2.1 & 1.77 & -0.032 & 0.06 & No change & No \\
\hline 25 & SEz & South-eastern, cyclonic & 1.4 & 1.53 & -0.059 & 0.13 & No change & No \\
\hline 26 & $\mathrm{Sa}$ & Southern, anticyclonic & 1.9 & 1.50 & -0.110 & 0.24 & Slight decrease & Yes \\
\hline 27 & $\mathrm{Sz}$ & Southern, cyclonic & 0.9 & 1.09 & 0.008 & 0.02 & No change & No \\
\hline 28 & TB & Depression over the British Isles, cyclonic & 2.3 & 1.91 & -0.039 & 0.07 & No change & No \\
\hline 29 & TRW & Trough over Western Europe, cyclonic & 3.9 & 2.59 & 0.427 & 0.55 & Moderate increase & Yes \\
\hline 30 & $\mathrm{X}$ & Unspecified/transient situation & 1.0 & 0.67 & 0.011 & 0.06 & No change & No \\
\hline
\end{tabular}


Fig. 7 Incidence $(N)$ of atmospheric circulation macrotypes according to the calendar by Hess and Brezowsky (1977) during the 1961-2000 period

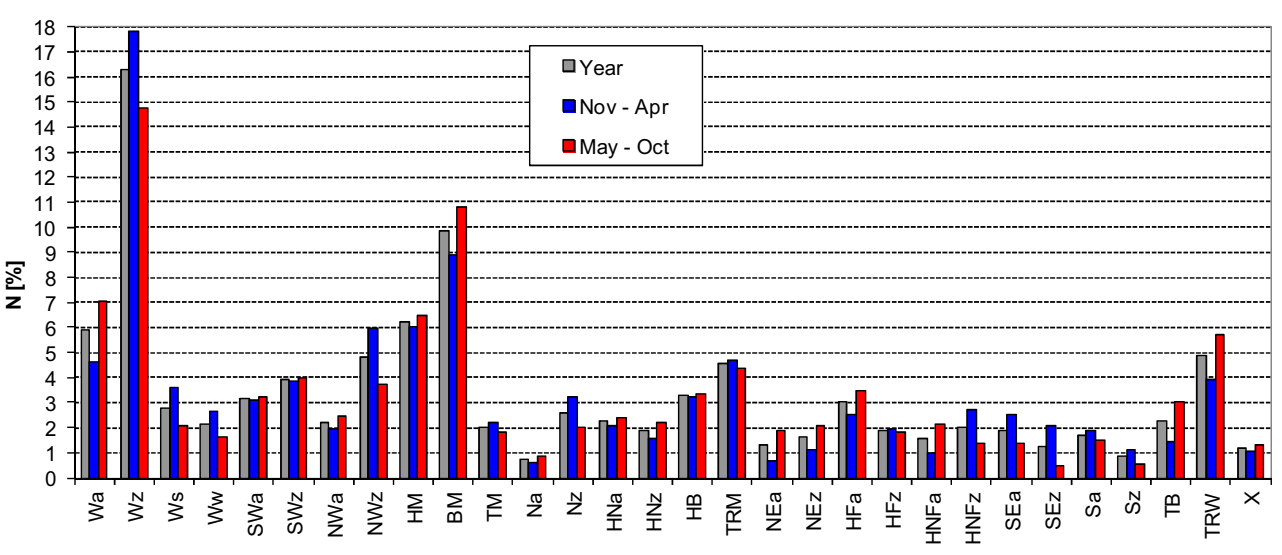

macro-types of atmospheric circulation meridional circulation patterns - a trough of low pressure over Western Europe blocked by high-pressure systems with their centre over the central Atlantic and over western Russia (TRW). There was also a moderate upward trend related to the circulation type with an anticyclonic ridge over Central Europe (BM), while the following types exhibited downward trends: NWa, HM, NEa (Table 2). The SWz circulation pattern generates an extensive atmospheric front zone with high levels of cloudiness in Western and Central Europe, bringing warming and precipitation. As a consequence, it contributes to a decrease in sunshine duration. The trends related to the changes in the circulation macro-types discussed are statistically significant at a significance level of 0.05 (Table 2).

For the purposes of analysing the impact of atmospheric circulation on sunshine duration, the period of simultaneous measurements of this parameter at both observatories (1961-
2000) was taken into consideration. The frequency distribution of circulation macro-types is analogous to their incidence in the 1901-2014 period. Moreover, the incidence of circulation types during the year for the 1961-2000 multi-annual period is similar to the frequency distribution in the warm and cold half-years (Fig. 7).

The shares of individual types of circulation patterns exhibit considerable variability from year to year and throughout the year. For instance, the incidence of the most common Wz circulation type (15.4\% on average) ranged from $2.7 \%$ in 1901 to $26.8 \%$ in 1994.

The average monthly differences in sunshine duration between Śnieżka and Szrenica ( $240 \mathrm{~m}$ lower) are positive for all months of the year. The average monthly difference is $10.6 \mathrm{~h}$. The largest average difference, amounting to $13.0 \mathrm{~h}$, is in March, while the lowest average difference is in October and
Fig. 8 Monthly differences (dSD) between sunshine duration on Śnieżka and Szrenica in the years 1961-2000

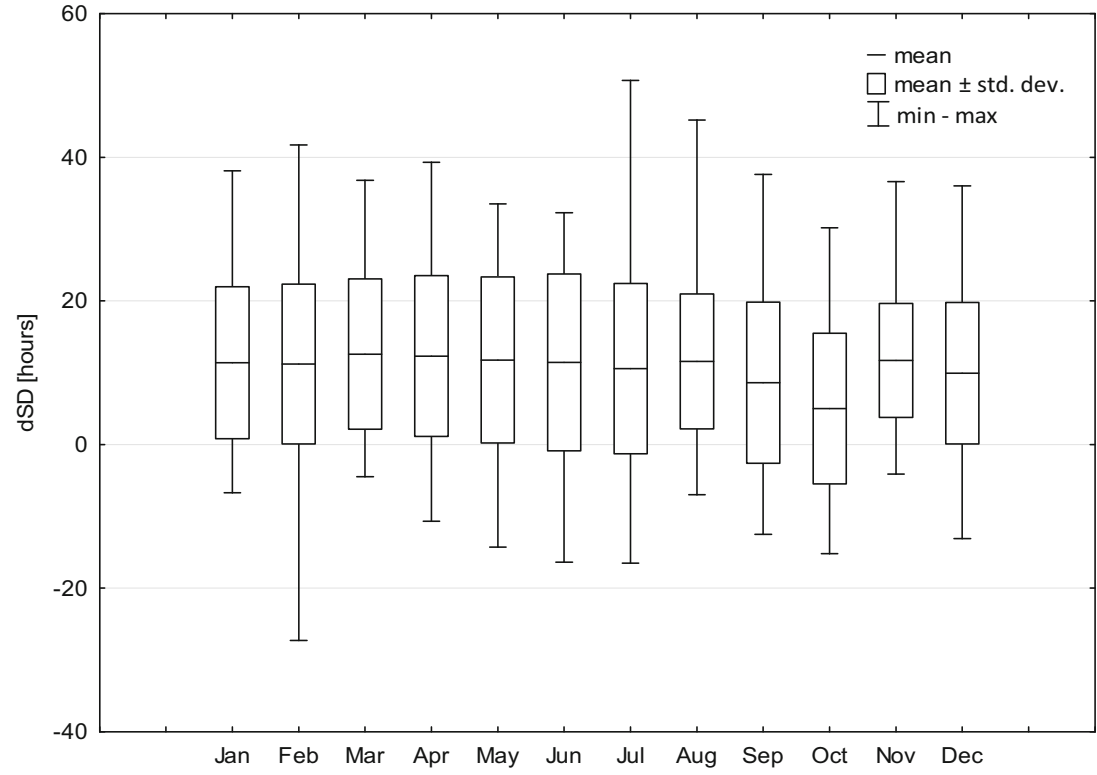


amounts to $5.0 \mathrm{~h}$. This means that the average radiation conditions on Śnieżka are more favourable compared to the main ridge of the Karkonosze range, which lies 200 to $250 \mathrm{~m}$ below it, i.e. at 1350-1400 m a.s.l. (Fig. 8). Maximum monthly differences in SD between $\mathrm{SN}$ and $\mathrm{SZ}$ are higher than minimum differences for each month. The average maximum monthly difference is $38.2 \mathrm{~h}$ while the average minimum monthly one is $12.4 \mathrm{~h}$. Similarly, the number of months with positive differences is approximately five times higher than the number of months with negative differences; on average, during the years analysed, these values amount to 31.4 and 6.1 , respectively.

The highest maximum differences were recorded in July 1974 and in August 1973, amounting to 51 and 45 h, respectively (Fig. 8). July 1974 was dominated by the following circulation macro-types: western cyclonic (Wz-48.4\%), western anticyclonic (Wa-19.4\%) and with troughs of low pressure over Western or Central Europe-TRW (16.1\%) and $\operatorname{TrM}(12.9 \%)$, respectively. On the other hand, in August 1973, the following circulation macro-types prevailed: high pressure over the North Sea- HNa and HNFa (19.4\% each) - and high pressure over Central Europe and Fennoscandia-BM and HFa (16.1\% each). The largest difference in sunshine duration in Szrenica's favour was recorded in February 1972 and amounted to $27 \mathrm{~h}$ (Fig. 8). At that time, south-eastern cyclonic circulation (SEz-44.8\%) dominated.

Average daily differences in sunshine duration between Śnieżka and Szrenica for individual circulation macro-types are positive during the year (apart from circulation patterns with advection from the south). The average daily SD on Śnieżka is higher than that recorded on Szrenica, and the difference ranges from $0.1 \mathrm{~h}$ for the HNFa macro-type to $0.5-$ $0.6 \mathrm{~h}$ for macro-types with advection of air masses from the north, i.e. $\mathrm{HB}, \mathrm{HNa}, \mathrm{Na}, \mathrm{Nz}, \mathrm{Nwa}$ and $\mathrm{NWz}$ and from the west, i.e. Wa and Wz. For the circulation macro-types mentioned, the average positive daily differences between Śnieżka and Szrenica are the highest in the cold half-year (XI-IV) and reach $0.7-0.8 \mathrm{~h}$ (Fig. 9). Only for southern circulation macrotypes (both during the year and in the warm and cold halfyears) is the average daily sunshine duration recorded on Śnieżka lower than that on Szrenica by ca. 0.1-0.4 h; for the southern cyclonic (Sz) pattern in the warm half-year, the difference may be as high as $1.1 \mathrm{~h}$ (Fig. 9). This is due to the fact that during the advection of warm air from the south not only does convection develop on the southern (windward) slopes of the Karkonosze range but the cloud base is lower as well. Therefore, Szrenica, which is ca. $240 \mathrm{~m}$ lower than Śnieżka and on the leeward side of the mountain range, is sometimes free of clouds during circulation macro-types with advection from the south and thus exhibits higher daily sunshine duration values than Śnieżka. Therefore, for the southern cyclonic circulation (Sz) macro-type, the maximum daily SD difference between $\mathrm{SN}$ and $\mathrm{SZ}$ is also the smallest and amounts to $4.6 \mathrm{~h}$ (Fig. 10).

Extreme daily differences in SD between Śnieżka and Szrenica for individual circulation macro-types in the 19612000 multi-annual period reach several hours (up to $10 \mathrm{~h}$ for the BM and SEz types) (Fig. 10). The highest positive difference was recorded on 21 September 1988 for the BM circulation macro-type and amounted to $10.7 \mathrm{~h}$. On the other hand, the two lowest negative differences occurred on 6 May 1985 and 5 October 1961 with southern circulation macro-types and amounted to 9.6 for $\mathrm{SEz}$ and $9.1 \mathrm{~h}$ for Sa, respectively (Fig. 10). The average maximum daily difference for all atmospheric circulation macro-types amounts to $7.3 \mathrm{~h}$, while the average minimum daily difference amounts to $-6.1 \mathrm{~h}$.

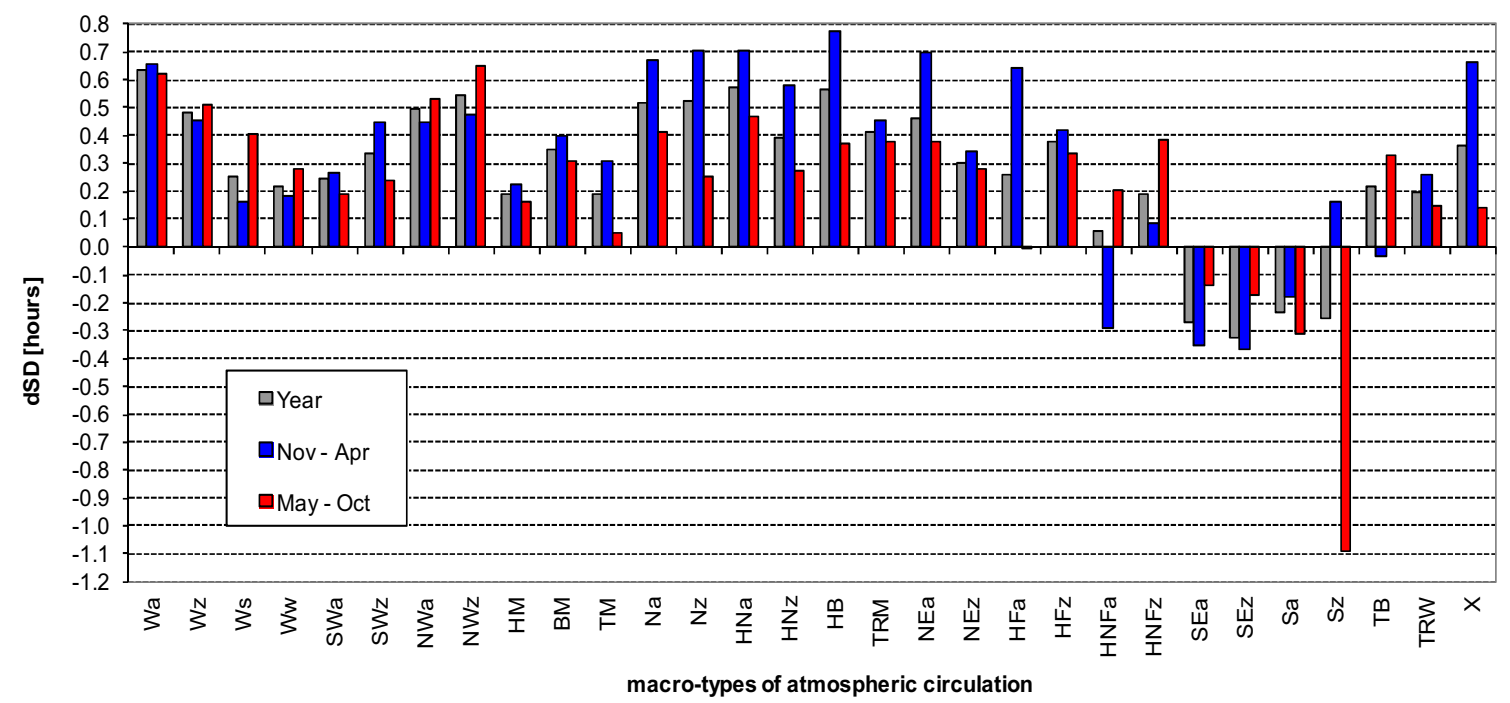

Fig. 9 Average daily differences in sunshine duration (dSD) between Śnieżka and Szrenica for individual atmospheric circulation macro-types during the 1961-2000 period 


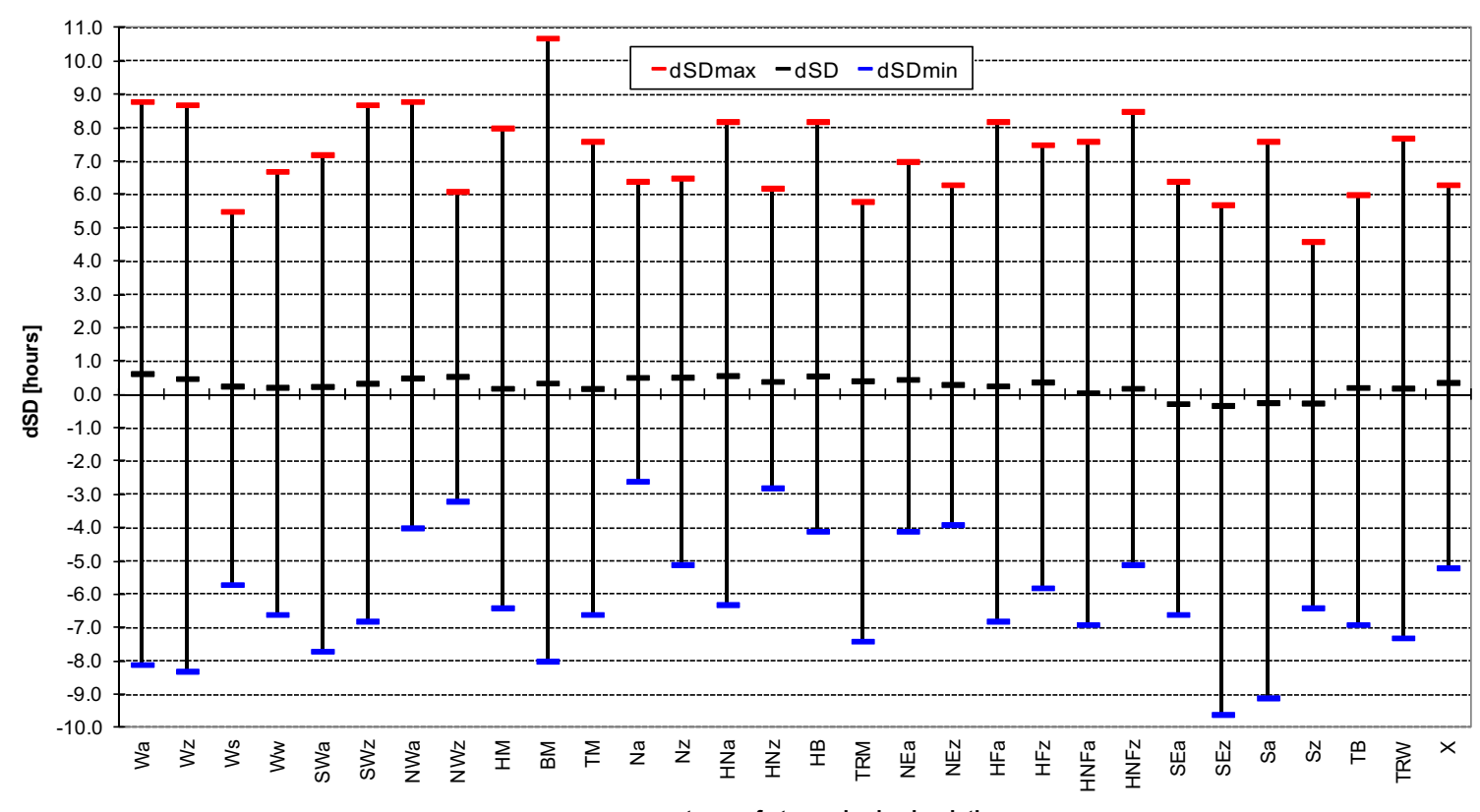

Fig. 10 Average (dSD), maximum (dSDmax) and minimum (dSDmin) daily differences in sunshine duration between Śnieżka and Szrenica for individual atmospheric circulation macro-types during the 1961-2000 period

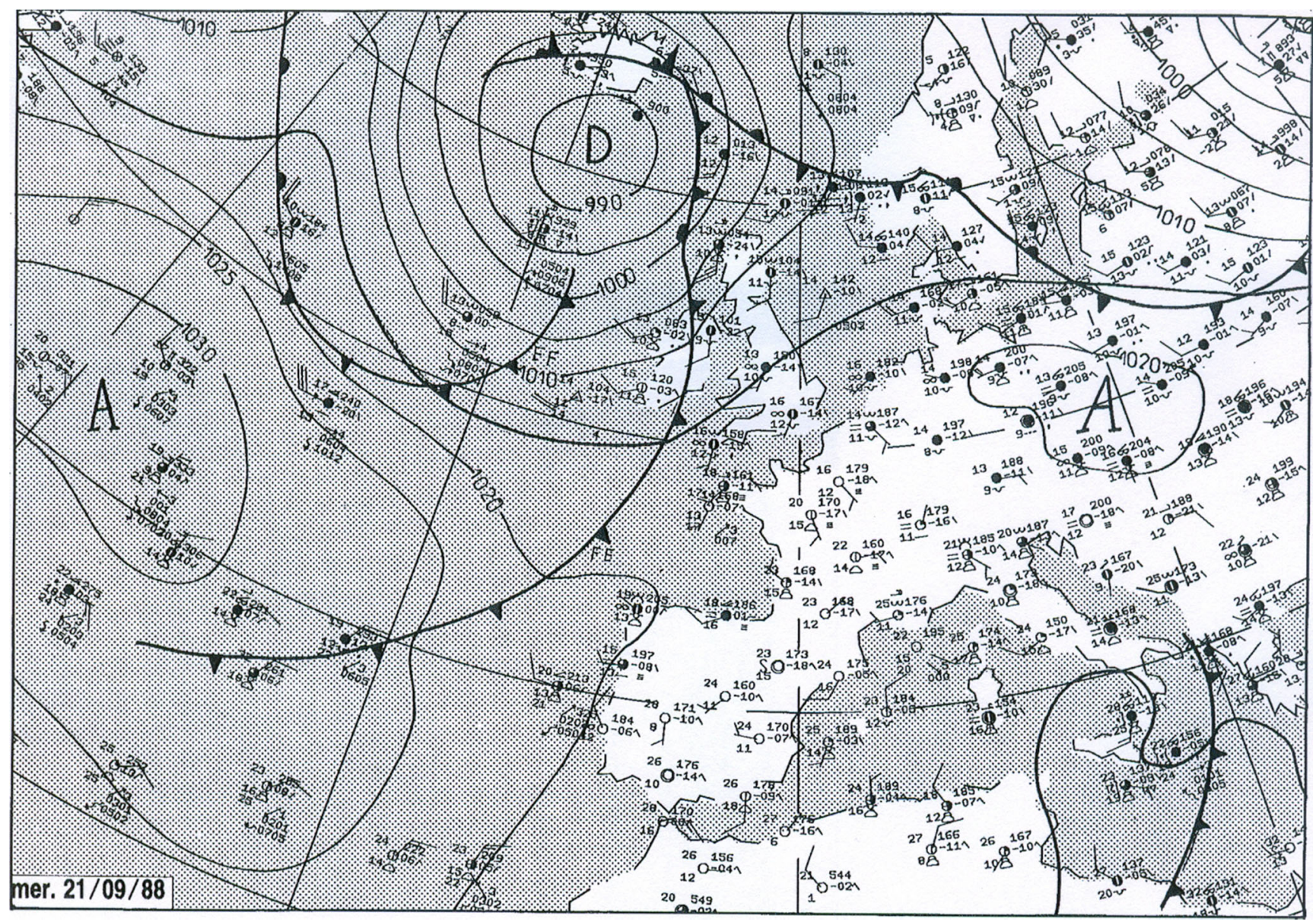

Fig. 11 Weather map of Europe for 21 September 1988 [source: https://donneespubliques.meteofrance.fr/; access: 17 February 2016] 


\subsubsection{Study of extreme cases}

Two extreme cases, i.e. with the highest positive and the highest negative differences of daily sunshine duration between Śnieżka and Szrenica, were subject to detailed analysis.

The first one (with the highest positive difference) occurred on 21 September 1988 for the BM circulation macro-type-a high-pressure ridge over Central Europe. The Karkonosze range was in a low-gradient pressure field at that time and was affected by the high-pressure ridge that extended from the middle of the Atlantic through Central Europe to the Caucasus (Fig. 11).

A vertical cross-section through the atmosphere obtained from aerological soundings taken over both Prague and Wrocław (the atmosphere sounding stations located closest to the Karkonosze range) indicated the presence of air with high relative humidity of up to $90-100 \%$ (Fig. 12) at altitudes of up to approx. $1300 \mathrm{~m}$ a.s.l. (in the Karkonosze range, which is ca. $100 \mathrm{~km}$ away, this ceiling was slightly higher as evidenced by the weather recorded on Szrenica and its location on the aerological diagram). The mixing ratio was $5.0-6.0 \mathrm{~g} / \mathrm{kg}$. Above this altitude, air with a very low temperature gradient with altitude was present but which also had a high dew-point gradient, which indicates low water vapour content-mixing ratio in the range of $3.0-2.0 \mathrm{~g} / \mathrm{kg}$. On Szrenica, observations taken at 6, 12 and 18 Universal Time Coordinated (UTC) recorded fog that limited visibility to $100 \mathrm{~m}$ and no sunshine. At the same time on Śnieżka, the cloud cover was low to moderate and the daily total of sunshine duration was $10.7 \mathrm{~h}$.
Direct solar radiation influenced the difference between the air temperatures measured at $12 \mathrm{pm}$-Śnieżka was as much as $6.6{ }^{\circ} \mathrm{C}$ warmer than Szrenica. At both stations, there was either a weak wind from the westerly sector or atmospheric silence (Tables 3 and 4).

The differences observed were caused by the situation where Śnieżka found itself in a layer of dry air with a gentle gradient of temperature decrease with absolute altitude. Air subsidence within the anticyclone (föhn in the free atmosphere) did not allow orographic lift to develop and there was direct solar radiation. On the other hand, Szrenica, $240 \mathrm{~m}$ lower down, experienced significantly different temperature and humidity conditions. Stagnant humid air resulted in all-day fog and a clear decrease in air temperature relative to Śnieżka.

The second extreme case (with the highest negative difference) was recorded on 6 May 1985 for the SEz circulation macro-type - south-eastern cyclonic advection of air masses. The Karkonosze range was then affected by a trough of low pressure with its centre over the British Isles (Fig. 13).

On the basis of the aerological diagram from Prague, it can be stated that on that date, the vapour condensation level was at an altitude of ca. $1400 \mathrm{~m}$ a.s.l., i.e. above Szrenica but below Śnieżka (Fig. 14). On Szrenica, strong and very strong wind from the easterly sector dominated during the day. On Śnieżka, very strong wind from the southerly sector dominated with an average speed of $18 \mathrm{~m} / \mathrm{s}$ (Table 3 ). The deviation of wind direction from the easterly to the southerly sector on Śnieżka was probably due to the air flow being channelled via the longitudinal Úpa River valley. On Szrenica, sunshine
Fig. 12 Aerological diagram for Prague from 12 UTC, 21 September 1988. Black bold line - lower limit of subsidence inversion/upper boundary of humid air; blue and red dotsrespective altitudes of Szrenica and Śnieżka (http://weather. uwyo.edu/upperair from 12 March 2016)

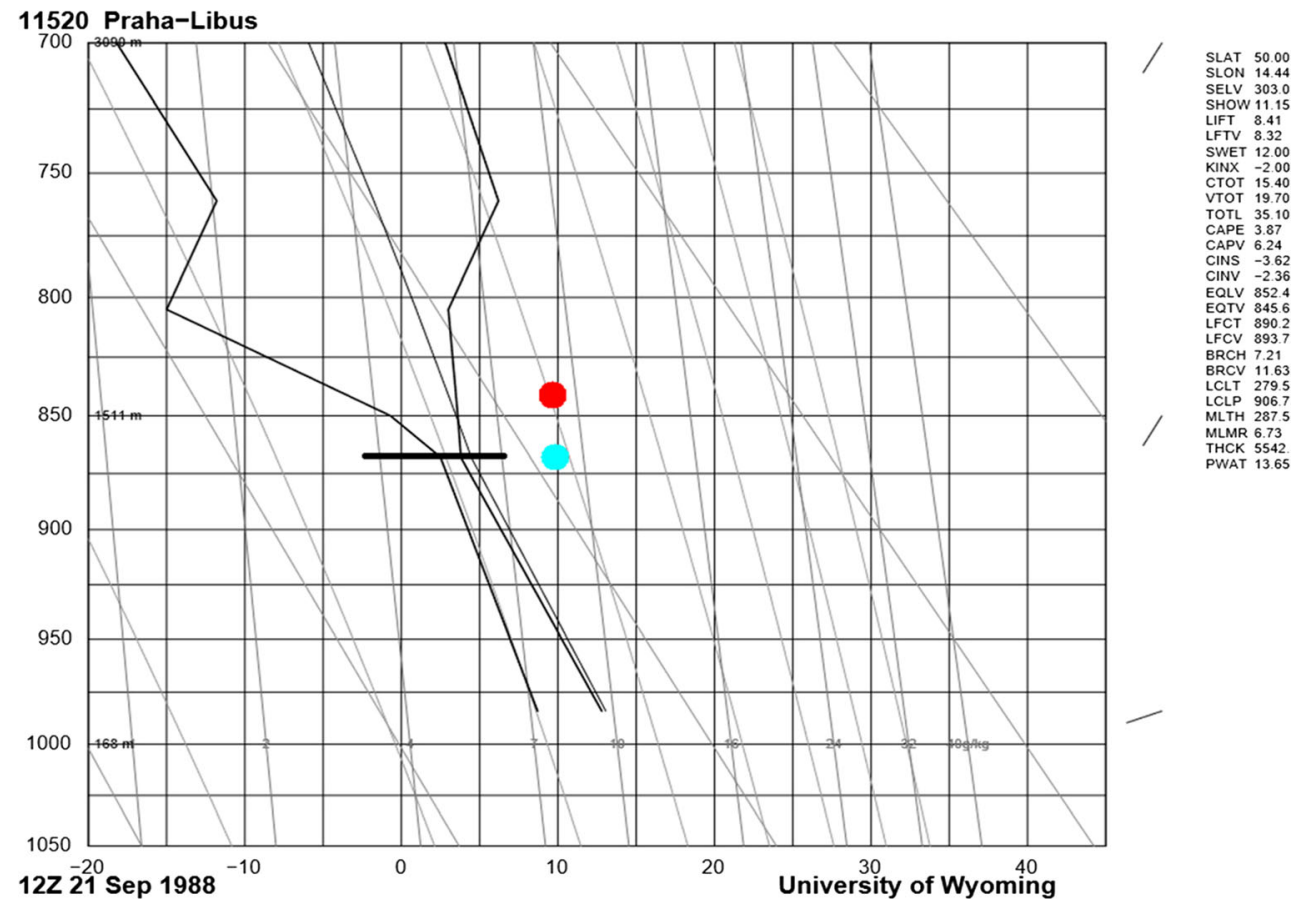


Table 3 Air temperature ( $T)$, relative air humidity $(U)$, wind direction $(A)$, average wind speed $(V)$ and cloud cover $(Z)[\mathrm{n}$ - sky overcast due to fog] on Śnieżka and Szrenica on 6 May 1985 and on 21 September 1988

\begin{tabular}{|c|c|c|c|c|c|c|c|}
\hline Date & Station & Time [UTC] & $T\left[{ }^{\circ} \mathrm{C}\right]$ & $U[\%]$ & $A\left[^{\circ}\right]$ & $V\left[\mathrm{~ms}^{-1}\right]$ & $Z[0-8]$ \\
\hline \multirow[t]{6}{*}{6 May 1985} & \multirow[t]{3}{*}{ Szrenica } & 6 & 3.5 & 100 & 120 & 10 & $\mathrm{n}$ \\
\hline & & 12 & 8 & 77 & 100 & 14 & 5 \\
\hline & & 18 & 7.4 & 83 & 120 & 17 & 6 \\
\hline & \multirow[t]{3}{*}{ Śnieżka } & 6 & 2.3 & 100 & 160 & 18 & $\mathrm{n}$ \\
\hline & & 12 & 2.8 & 97 & 180 & 18 & 7 \\
\hline & & 18 & 6.2 & 97 & 200 & 14 & 7 \\
\hline \multirow[t]{6}{*}{21 Sep 1988} & \multirow[t]{3}{*}{ Szrenica } & 6 & 3.1 & 100 & 280 & 2 & $\mathrm{n}$ \\
\hline & & 12 & 4.7 & 100 & 200 & 1 & $\mathrm{n}$ \\
\hline & & 18 & 4 & 100 & 0 & 0 & $\mathrm{n}$ \\
\hline & \multirow[t]{3}{*}{ Śnieżka } & 6 & 8.6 & 44 & 270 & 2 & 2 \\
\hline & & 12 & 11.3 & 66 & 0 & 0 & 4 \\
\hline & & 18 & 8.8 & 20 & 0 & 0 & 2 \\
\hline
\end{tabular}

was only recorded from 9 am after the morning mist had subsided. It ended after $7 \mathrm{pm}$. The daily total of sunshine duration on Szrenica was $9.6 \mathrm{~h}$ (Table 4). At the main observation hours, the cloudiness recorded on Śnieżka was high (the sky was almost overcast) The influence of sunshine duration was reflected in the air temperature value at $12 \mathrm{pm}$, which was $5.2{ }^{\circ} \mathrm{C}$ higher on Szrenica than on Śnieżka (more than $3{ }^{\circ} \mathrm{C}$ warmer taking into account the temperature differences resulting from absolute altitude, with the temperature reduced according to the wet adiabatic lapse rate) (Table 3 ).

The reason for the large negative difference $(9.6 \mathrm{~h})$ in sunshine duration between Śnieżka and Szrenica for the southern circulation macro-type was the fact that, apart from the main ridge of the Karkonosze range, the isolated Śnieżka summit constituted an additional orographic barrier to air advection from the south. The forced orographic lift led to the condensation of water vapour above $1414 \mathrm{~m}$, i.e. above the peak of Szrenica. The result was a cap cloud that covered the Śnieżka summit. Additionally, given circulation from the ESE-SE, Szrenica was on the leeward side of the other Karkonosze range elevations (Fig. 1a). The shielding afforded by these summits could have caused air subsidence on the Karkonosze range mesoscale and the further disintegration of cloud cover over the Szrenica summit. The effect was almost uninterrupted sunshine during the day despite the relatively high degree of cloudiness. The strong wind continued to move the clouds around so they could not obscure the solar disc for a long time.

\subsection{Summary and conclusions}

Sunshine duration on Śnieżka (SN) exhibits a strong positive correlation with sunshine duration on Szrenica (SZ) for annual, seasonal and monthly totals. The correlation coefficient $(R)$ ranges from 0.81 in winter to $0.94-0.97$ in other seasons and over the entire year. The average annual total of sunshine duration in the 1901-2014 multi-annual period on Śnieżka is $1423.0 \mathrm{~h}$.

During the year, the highest average SD values were found for the following months (in descending order): May (171.7 h), July (167.9 h) and August (163.8 h). The May SD maximum is the result of low degrees of cloudiness, which is due to the limited share of western cyclonic (Wz) circulation during this month; the annual share of this circulation macrotype stands out compared to the other macro-types. The lowest average monthly SD total occurs in December at $63.1 \mathrm{~h}$. This is due to the low position of the sun above the horizon and the short day. On average, over a year, the main ridge of the Karkonosze range receives $31 \%$ of potential sunshine duration.

Table 4 Sunshine duration in hourly intervals on 6 May 1985 and 21 September 1988

\begin{tabular}{|c|c|c|c|c|c|c|c|c|c|c|c|c|c|c|c|c|c|}
\hline \multirow[t]{2}{*}{ Date } & \multirow[t]{2}{*}{ Station/UTC } & \multicolumn{15}{|c|}{ Hourly totals of sunshine duration } & \multirow[t]{2}{*}{ Daily sum } \\
\hline & & 6 & 7 & 8 & 9 & 10 & 11 & 12 & 13 & 14 & 15 & 16 & 17 & 18 & 19 & 20 & \\
\hline \multirow[t]{2}{*}{6 May 1985} & Szrenica & - & - & - & 0.6 & 1.0 & 0.9 & 0.6 & 1.0 & 1.0 & 0.9 & 1.0 & 1.0 & 1.0 & 0.6 & - & 9.6 \\
\hline & Śnieżka & - & - & - & - & - & - & - & - & - & - & - & - & - & - & - & - \\
\hline \multirow[t]{2}{*}{21 Sep 1988} & Szrenica & - & - & - & - & - & - & - & - & - & - & - & - & - & - & - & - \\
\hline & Śnieżka & - & 0.4 & 1.0 & 1.0 & 1.0 & 1.0 & 1.0 & 1.0 & 1.0 & 1.0 & 1.0 & 1.0 & 0.3 & - & - & 10.7 \\
\hline
\end{tabular}




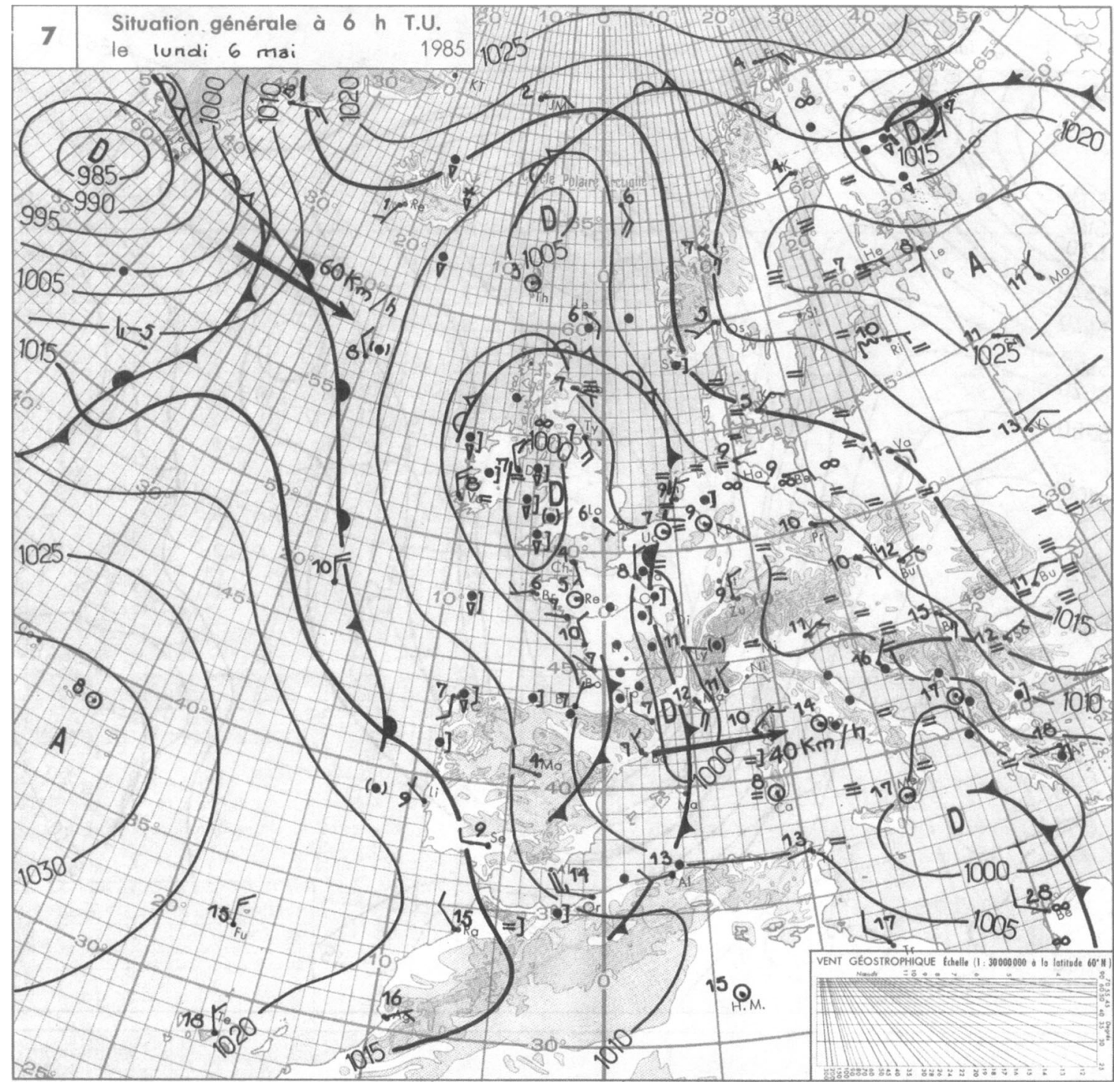

Fig. 13 Weather map of Europe for 6 May 1985 [source: https://donneespubliques.meteofrance.fr/; access: 17 February 2016]

The results of the spectral analysis of sunshine duration on Śnieżka in the years 1901-2014 point to the existence of two cycles: a short one of approx. 2-4 years and a long one of approx. 60 years. The former most probably reflects the rhythm of atmospheric circulation in the North Atlantic (North Atlantic Oscillation), while the latter reflects the impact of ocean circulation associated with the AMO (Atlantic Multidecadal Oscillation) mechanism. Similar relationships have been identified in the case of multi-annual changes in air temperature in the Karkonosze range.

Within the 114-year series of annual totals of sunshine duration on Śnieżka, a slight positive trend has been identified, which is not statistically significant at a significance level of 0.05 . Nevertheless, three periods can be distinguished: two with a rising trend (from the beginning of measurements until the 1920s and from the late 1990s until the present) and one with a falling trend (from the early 1950s until the early 1980s). SD trends in the aforementioned periods closely followed the trends observed in other areas of Europe and of the world.

Average monthly differences in sunshine duration between Śnieżka and Szrenica (240 m lower) are positive for all months of the year. The average monthly difference is ca. 10 to $11 \mathrm{~h}$. This means that the average radiation conditions on Śnieżka are more favourable than the main ridge of the Karkonosze range, which lies at an altitude 200 to $250 \mathrm{~m}$ lower, i.e. at 1350-1400 m a.s.l. Maximum monthly differences in SD between $\mathrm{SN}$ and $\mathrm{SZ}$ are higher than minimum differences for each month. The average maximum monthly difference is around $38 \mathrm{~h}$ while the average minimum monthly difference is $12 \mathrm{~h}$. 
Fig. 14 Aerological diagram for Prague from 12 UTC, 6

May 1985. Black bold line-level of vapour condensation, blue and red dots - respective altitudes of Szrenica and Śnieżka (http://weather.uwyo.edu/upperair from 12 March 2016)

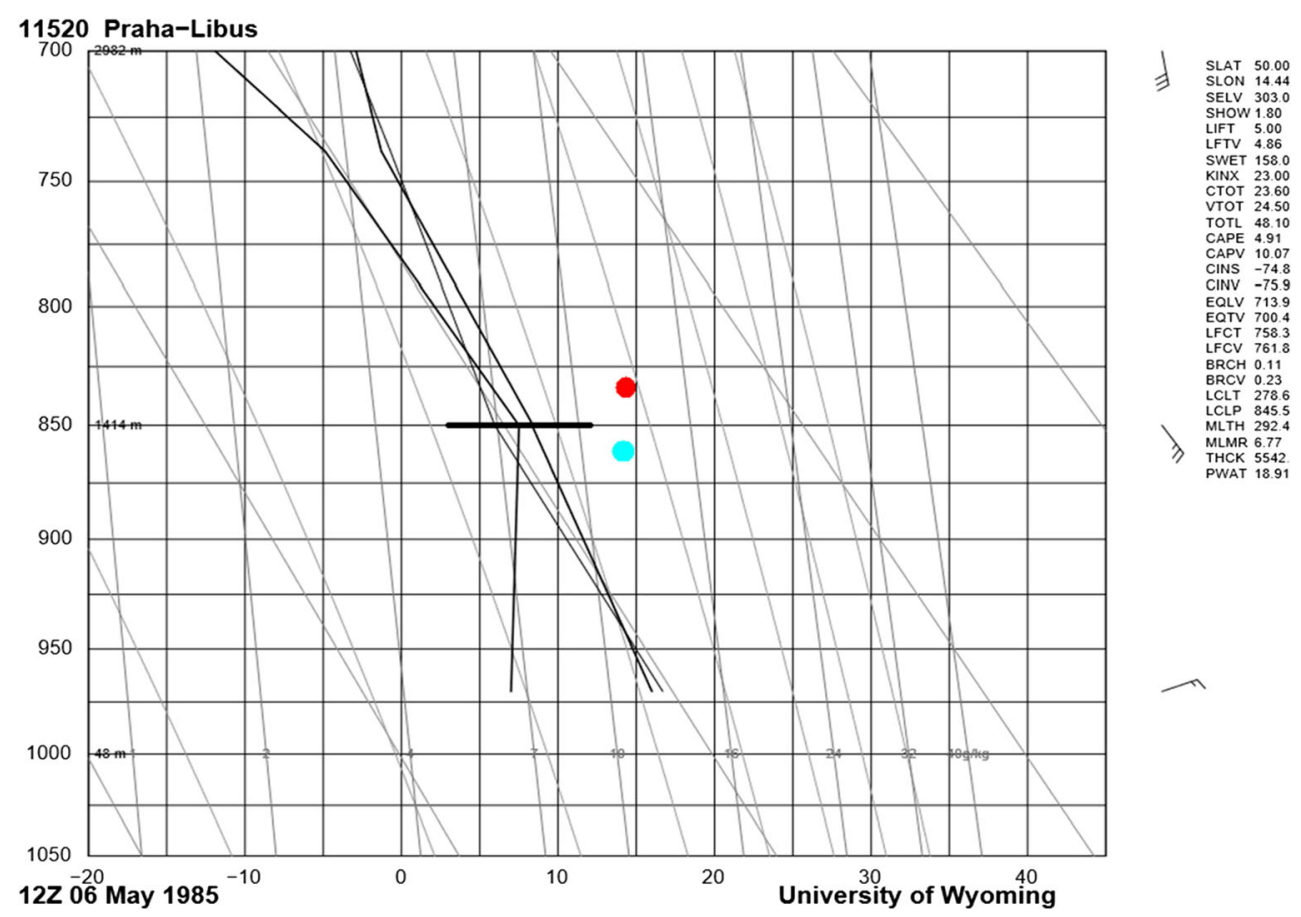

Average daily differences in sunshine duration between Śnieżka and Szrenica for individual circulation macro-types (apart from circulation patterns with advection from the south) are positive during the year. The average daily SD on Śnieżka is higher than that recorded on Szrenica, and the difference ranges from $0.1 \mathrm{~h}$ for the HNFa macro-type to $0.5-0.6 \mathrm{~h}$ for macro-types with advection of air masses from the north, i.e. $\mathrm{HB}, \mathrm{HNa}, \mathrm{Na}, \mathrm{Nz}, \mathrm{NWa}$ and NWz and from the west, i.e. Wa and Wz. For the circulation macro-types mentioned, the average positive daily differences between Śnieżka and Szrenica are the highest in the cold half-year (XI-IV) and reach $0.7-$ $0.8 \mathrm{~h}$. Only for southern circulation macro-types (both during the year and in the warm and cold half-years) is the average daily sunshine duration recorded on Śnieżka lower than that on Szrenica by ca. 0.1-0.4 h; for the Sz type in the warm halfyear, the difference may be as high as $1.1 \mathrm{~h}$.

In the orographic conditions found on the Karkonosze range, two phenomena contribute to the occurrence of extreme differences in daily sunshine duration between the higher Śnieżka (1603 m a.s.l.) and Szrenica (1362 m a.s.l.). The largest positive differences are caused by anticyclonic air subsidence and the presence of a sea of fog below the Śnieżka summit. The largest negative differences (higher totals of SD on Szrenica) occur during air advection from the south and subsidence and orographic lifting on the slopes of the isolated Śnieżka massif. Extreme daily differences in SD between Śnieżka and Szrenica for individual circulation macro-types in the 1961-2000 multi-annual period reach several hours (up to $10 \mathrm{~h}$ for the BM and SEz types). The average maximum daily difference for all atmospheric circulation macro-types between Śnieżka and Szrenica amounts to $+7.3 \mathrm{~h}$, while the average minimum daily difference amounts to $-6.1 \mathrm{~h}$.

The sunshine duration measurement series for Śnieżka is one of the longest mountain series in Europe. The observed sunshine duration trends are in line with the trends recorded for this meteorological parameter elsewhere in the world. Therefore, Śnieżka is a good place to study long-term sunshine duration trends. Additionally, the location of the Śnieżka observatory on the highest summit of the Sudetes, which is not influenced by local anthropogenic factors, makes it possible to conduct reliable analyses of the parameters measured there in connection with atmospheric circulation.

Open Access This article is distributed under the terms of the Creative Commons Attribution 4.0 International License (http:// creativecommons.org/licenses/by/4.0/), which permits unrestricted use, distribution, and reproduction in any medium, provided you give appropriate credit to the original author(s) and the source, provide a link to the Creative Commons license, and indicate if changes were made.

\section{References}

Angell JK (1990) Variation in United States cloudiness and sunshine duration between 1950 and the drought year of 1988. J Clim 3: 296-308. doi:10.1175/1520-0442(1990)003<0296:viusca>2.0.co;2

Angell JK, Korshover J, Cotton GT (1984) Variation in United States cloudiness and sunshine, 1950-1982. JClim Appl Meteorol 23. doi:10.1175/1520-0450(1984)023<0752:viusca >2.0.co;2 
Auer I, Böhm R, Mohnl H (1990) Die troposphärische Erwärmungsphase des 20. Jahrhunderts im Spiegel der 100-jährigen Meßreihe des alpinen Gipfelobservatoriums auf dem Sonnblick. CIMA ' 88 Proceedings of the 20th International Tagung für Alpine Meteorologie. Rome, Italian Meteorological Service

Bednar J (1990) Recent changes of the sunshine in Prague region. In: Brázdil R (ed) Climatic change in the historical and the instrumental periods. Masaryk University, Brno, pp 240-242

Błaś M, Sobik M (2000) Mgła w Karkonoszach i wybranych masywach górskich Europy (Fog in the Giant Mountains and selected European massifs). Opera Corcon 37(1):35-46 (in Polish)

Brázdil R (1991) Národní klimatický program ČR svazek 2: Kolísání vybraných meteorologických prvků ve střední Evropě v období prístrojových pozorování Praha

Brázdil R, Flocas AA, Sahsamanoglou HS (1994) Fluctuation of sunshine duration in central and South-Eastern Europe. Int J Climatol 14(9):1017-1034. doi:10.1002/joc.3370140907

Dobesch H (1992) On the variations of sunshine duration in Austria. Theor Appl Climatol 46:33-38. doi:10.1007/bf00866445

Dubicka M (1997) 95-letnia seria rejestracji usłonecznienia na Śnieżce (95 Year's series recording sunshine duration At Śnieżka Mt.). Geoekologiczne Problemy Karkonoszy. Materiały z sesji naukowej w Przesiece 15-18.X.1997, pp 133-144 (in Polish)

Dubicka M, Karal J (1994) Usłonecznienie na Szrenicy i jego związek z cyrkulacją atmosfery (Sunshine duration on Szrenica Mt. and its relation to the atmospheric circulation). Acta Uniwersitatis Wratislaviensis No 1590. Prace Instytutu Geograficznego, seria C. Meteorologia i Klimatologia 1:9-43 (in Polish)

Dubicka M, Limanówka D (1994) Zmienność zachmurzenia i usłonecznienia w Sudetach i Karpatach oraz na ich przedpolu (Variability of cloud cover and sunshine duration in the Sudety Mountains and Karpaty Mountains as well as on their foreland). Acta Uniwersitatis Wratislaviensis No 1590. Prace Instytutu Geograficznego, seria C. Meteorologia i Klimatologia 1:45-60 (in Polish)

Ellenberg H (1978) Vegetation Mitteleuropas mit den Alpenin Ökologischer Sicht. Eugen Ulmer, Stuttgart

Enfield DB, Mestas-Nunez AM, Trimble PJ (2001) The Atlantic Multidecadal Oscillation and its relationship to rainfall and river flows in the continental U.S. Geophys Res Lett 28:2077-2080. doi:10.1029/2000gl012745

Głowicki B (1995) Klimat Śnieżki (Climate of Mount Śnieżka). In: Dubicki A, Głowicki B (eds) Wysokogórskie Obserwatorium Meteorologiczne na Śnieżce. PIOŚ, IMGW, Wrocław, pp 37-64 (in Polish)

Henderson-Sellers A (1986) Cloud changes in a warmer Europe. Clim Chang 8:25-52. doi:10.1007/bf00158968

Hess M (1968) Piętra klimatyczne w Alpach Wschodnich, Karpatach Zachodnich i w Sudetach (Vertical climatic zones in the Eastern Alps, the Western Carpathians and the Sudetes). Prz Geogr 40(2): 467-472 (in Polish)

Hess P, Brezowsky H (1952) Katalog der Großwetterlagen Europas. Ber. Dtsch. Wetterd. US-Zone

Hess P, Brezowsky H (1977) Katalog der Großwetterlagen Europas 1881-1976, 3. Auflage, Ber. Dtsch. Wetterd. 113

Horecka V (1990) Trend of sunshine in Slovakia. In: Brázdil R (ed) Climatic change in the historical and the instrumental periods. Masaryk University, Brno, pp 246-248

Jhajharia D, Singh VP (2011) Trends in temperature, diurnal temperature range and sunshine duration in Northeast India. Int J Climatol 31: 1353-1367. doi:10.1002/joc.2164

Kaiser DP, Qian Y (2002) Decreasing trends in sunshine duration over China for 1954-1998: indication of increased haze pollution? Geophys Res Lett 29:2042-2045. doi:10.1029/2002GL016057
Kerr A, Tabony R (2004) Comparison of sunshine recorded by Campbell-Stokes and automatic sensors. Weather 59(4):90-95. doi:10.1256/wea.99.03

Kuczmarski M (1990) Usłonecznienie Polski i jego przydatność dla helioterapii (The sunshine duration in Poland and its significance for heliotherapeutic purpose). Dok. Geogr., 4. IGiPZ PAN. Wrocław-Warszawa-Kraków, 69 (in Polish)

Kwiatkowski J, Hołdys T (1985) Klimat (Climate). In: Jahn A. (ed) Karkonosze polskie, Ossolineum, pp 87-116 (in Polish)

Liepert BG (2002) Observed reductions of surface solar radiation at sites in the United States and worldwide from 1961 to 1990. Geophys Res Lett 29:1421-1424. doi:10.1029/2002GL014910

Limanówka D, Ustrnul Z (1993) Changes of sunshine in the altitude profile of the Polish Western Carpathians. Zesz Nauk Uniw Jagiell, Pr Geogr 95:116-124

Lorenc H, Bogdańska B, Dołęga E, Kowalewski M, Laskowska A, Witaszczyk M, Skibowska E (2005) Atlas klimatu Polski (Climate atlas of Poland). IMGW, Warszawa, p 116 (in Polish)

Matuszko D (2014) Long-term variability in solar radiation in Krakow based on measurements of sunshine duration. Int J Climatol 34:228 234. doi:10.1002/joc.3681

Michalczewski J (1959) Usłonecznienie i zachmurzenie Zakopanego w latach 1924-1948 (Sunshine duration and cloud cover of Zakopane in 1924-1948). Wiad Służ Hydrol Meteorol 6:5 (in Polish)

Migała K, Liebersbach J, Sobik M (2002) Rime in the Giant Mts. (the Sudetes, Poland). Atmos Res 64:63-73. doi:10.1016/S0169-8095 (02)00080-7

Migała K, Urban G, Tomczyński K (2015) Long term air temperature variation in the Karkonosze mountains according to atmospheric circulation. Theor Appl Climatol doi. doi:10.1007/s00704-015$1468-0$

Morawska-Horawska M (1984) Współczesne zmiany w zachmurzeniu i usłonecznieniu Krakowa na tle 120-lecia (Contemporary changes of cloudiness and sunshine duration in Cracow on the background of 120 years). Prz Geofiz 29(3):271-284 (in Polish)

Morawska-Horawska M (1985) Cloudiness and sunshine in Cracow, 1861-1980, and its contemporary tendencies. Int J Climatol 5:633642. doi:10.1002/joc.3370050605

Oman L, Robock A, Stenchikov G, Schmidt GA, Ruedy R (2005) Climatic response to high-latitude volcanic eruptions. J Geophys Res 110(D13). doi:10.1029/2004JD005487

Orliczowa J (1968) Zachmurzenie i usłonecznienie regionu tatrzańskiego (Cloud cover and sunshine duration in Tatra Region). Seria Materiały PIHM, Zakopane, Warszawa, Wrocław (in Polish)

Pallé E, Butler CJ (2001) Sunshine records from Ireland: cloud factors and possible links to solar activity and cosmic rays. Int J Climatol 21:709-729. doi:10.1002/joc.657

Pinker RT, Zhang B, Dutton EG (2005) Do satellites detect trends in surface solar radiation? Science 308:850-854. doi:10.1126 /science. 1103159

Portis DH, Walsh JE, Hamly ME, Lamb PJ (2001) Seasonality of the North Atlantic Oscillation. J Clim 14(9):2069-2078. doi:10.1175 /1520-0442(2001)014<2069: sotnao >2.0.co;2

Raichijk C (2012) Observed trends in sunshine duration over South America. Int J Climatol 32:669-680. doi:10.1002/joc.2296

Sanchez-Lorenzo A, Brunetti B, Calbó J, Martin-Vide J (2007) Recent spatial and temporal variability and trends of sunshine duration over the Iberian Peninsula from a homogenized data set. J Geophys Res 112:D20. doi:10.1029/2007JD008677

Sanchez-Lorenzo A, Calbó J, Martin-Vide J (2008) Spatial and temporal trends in sunshine duration over Western Europe (1938-2004). J Clim 21(22):6089-6098. doi:10.1175/2008jcli2442.1

Schlesinger ME, Ramankutty N (1994) An oscillation in the global climate system of period 65-70 years. Nature 367(6465):723-726. doi:10.1038/367723a0 
Sobik M, Błaś M, Migała K, Godek M, Nasiółkowski T (2014) Klimat (Climate). In: Knapik R, Raj A (eds) Przyroda Karkonoskiego Parku Narodowego. Karkonoski Park Narodowy, Jelenia Góra, pp 147 186 (in Polish)

Stanhill G, Cohen S (2001) Global dimming: a review of the evidence for a widespread and significant reduction in global radiation with discussion of its probable causes and possible agricultural consequences. Agric For Meteorol 107:255-278. doi:10.1016/s01681923(00)00241-0

Stanhill G, Cohen S (2005) Solar radiation changes in the United States during the twentieth century: evidence from sunshine duration measurements. J Clim 18:1503-1512. doi:10.1175/jcli3354.1

Stenz E (1959) Niektóre dane o promieniowaniu słonecznym w Karpatach, Sudetach i ich przedgórzu. (Some data on insolation in the Carpathians, Sudetes and their foreland). Acta Geophys Pol 7(1): 12-24 (in Polish)

Trybowski C (1955) Zachmurzenie i usłonecznienie Rabki (Cloud cover and sunshine duration over Rabka) Wiad Służ Hydrol Meteorol, 5, 1 (in Polish)

Vaniček K (1990) Trendy slunečniho svitu na územi ČSR v obdobi 1956 85. In: Sbornik praci Českeho Hydrometeorologického. Ústavu, 37. Praha
Weber GR (1990) Spatial and temporal variations of sunshine in the Federal Republic of Germany. Theor Appl Climatol 41:1-9. doi:10.1007/bf00866197

Werner PC, Gerstengarbe FW (2010) Katalog der Grosswetterlagen Europas (1881-2009) nach Paul Hess und Helmut Brezowsky 7., verbesserte und ergänzte auflage. PIK Report https:/www.pikpotsdam.de/research/publications/pikreports/.files/pr119.pdf. Accessed 16 May 2016

Wild M (2009) Global dimming and brightening: a review. J Geophys Res 114:D00D16. doi:10.1029/2008JD011470

Wild M, Gilgen H, Roesch A, Ohmura A, Long CL, Dutton EG, Forgan B, Kallis A, Russak V, Tsvetkov A (2005) From dimming to brightening: decadal changes in solar radiation at Earth's surface. Science 308:847-850. doi:10.1126 /science. 1103215

Yang YH, Zhao N, Hao XH, Li CQ (2009) Decreasing trend of sunshine hours and related driving forces in North China. Theor Appl Climatol 97:91-98. doi:10.1007/s00704-008-0049-x

Zhang XJ, Jin LY, Chen CZ, Guan DS, Li MZ (2011) Interannual and interdecadal variations in the North Atlantic Oscillation spatial shift. Chin Sci Bull 56(24):2621-2627. doi:10.1007 /s11434-011-4607-8 